prof. dr. sc. Stanko Geić ${ }^{1}$

dr. sc. Marijana Jurišić, pred. ${ }^{2}$

mr. sc. Jakša Geić, v. pred. ${ }^{3}$

\title{
SOCIOKULTURNE REMINISCENCIJE PANDEMIJA, ZDRAVSTVENE KULTURE I TURIZMA U DALMACIJI
}

\author{
Izvorni znanstveni rad / Original scientific paper \\ UDK/UDC: 616.036.2:338.38 \\ DOI: $10.51650 /$ ezrvs.15.1-2.1 \\ Primljeno / Received: 28/2/2021 \\ Prihvaćeno / Accepted: 2/6/2021
}

Čovječanstvo je kroz svoju milenijsku povijest slijedom permanentnih migracija, a uz nedostatnu razinu zdravstvene kulture i infrastrukture, od pamtivijeka suočeno s brojnim zaraznim bolestima pa i globalnim pandemijama. Među najpoznatijim i najstrašnijim pandemijama kojima je izvorište i žarište najčešće bilo u području Dalekog istoka s niskom zdravstvenom kulturom bile su pandemije lepre, kuge, boginja, kolere, tuberkuloze, malarije, pa i najnovija pandemija Corona virusa SARS Cov-2 Covid-19. One su zahvaćale i naše krajeve, pa i Dalmaciju koja je oduvijek imala razgranate komunikacije diljem Mediterana i svijeta. Katastrofalne razmjere globalnih pandemija o kojima je riječ pokazuju procjene suvremenih istraživača koje govore da je, primjerice, tijekom povijesti samo od brojnih pandemija kuge umrlo preko pola milijarde ljudi ili 2/3 žitelja Europe. Razvoj masovnog turizma uz sve zdravstvene pogodnosti privremene promjene radne i životne sredine slijedom globalnih interkontinentalnih migracija, $u$ isto vrijeme rezultira velikim polucijama i destrukcijom okoliša te intenzivnim kontaktima stvara pogodno tlo za širenje pandemija, pa je turističko ugostiteljski sektor uvijek prvi na udaru restrikcija s velikim socio gospodarskim posljedicama. Pozitivna, ali i negativna iskustva, te razmjere pandemija i aktivnosti za njihovo sprječavanje te suzbijanje, u radu se sagledavaju na globalnom planu te posebice prostoru kroz vjekove glasovite hrvatske regije Dalmacije, kao razmeđi europskih demografskih, gospodarskih i kulturnih komunikacija. Spoznaja i analiziranje pojavnosti i zakonitosti nastanka, razvoja, širenja te vremensko trajanje i periodično ponavljanje pandemija, pa i njihovo suzbijanje i preveniranje kroz milenijsku povijest, što se uz sociokulturne interakcije s turizmom razmatra u ovom radu, može biti dragocjen orijentir i u aktualnoj pandemiji. Ona je ozbiljno zaprijetila svijetu s preko 100 milijuna oboljelih i 2 milijuna preminulih (do 31. 01.2021.), uz zabrinjavajuću progresiju koja unatoč naporima prenapregnute zdravstveno epidemiološke struke i pronalaska cjepiva,

\footnotetext{
1 Visoka škola za menadžment i dizajn ASPIRA; e-mail: stanko.geic@aspira.hr

${ }^{2}$ Visoka škola za menadžment i dizajn ASPIRA; e-mail: marijana.jurisic@aspira.hr

${ }^{3}$ Visoka škola za menadžment i dizajn ASPIRA; e-mail: jaksageic1@gmail.com
} 
pojavom novih sojeva i mutacijom virusa, ne jenjava. Problemi su evidentni i u Dalmaciji te Hrvatskoj u cjelini, koja je prema broju zaraženih po stanovniku krajem prosinca i početkom siječnja bila među najugroženijim zemljama EU, uz ukupno 200.000 oboljelih i 5.000 preminulih. Međutim uz poduzete drastične mjere Nacionalnog stožera, situacija s pandemijom u RH pa i Dalmaciji postupno jenjava, što uz intenzivno procjepljivanje pučanstva omogućava daljnje oprezno popuštanje mjera s nakanom da Hrvatska kao "corona free" destinacija dočeka turističku sezonu o kojoj ovisi dalmatinsko pa i cjelokupno hrvatsko gospodarstvo.

Ključne riječi: turizam, Covid 19, zdravstvena kultura, pandemije, povijest, Dalmacija.

\section{Uvod}

„Grke je poharala kuga." (Homer - Ilijada, 8. st. p.n.e.)

„U Trogiru više ne postoji malarija i boravak stranaca s tog gledišta može biti trajan." (Higijenski zavod Kraljevine Jugoslavije, 14. lipnja 1931.)

„Globalna pandemija Korona virusa SARS-CoV 2 Covid 19 sa žarištem u Wuhanu te potom u Bergamu zahvatila je sve zemlje svijeta, što je presedan u povijesti. ( HTV, 01. 05. 2020).

Čovječanstvo je od pamtivijeka suočeno s brojnim, često neobjašnjivim bolestima, epidemijama i pandemijama koje su znale decimirati, a katkada i istrijebiti pučanstvo na određenim područjima zemaljske kugle. U tom kontekstu izuzetno je aktualna globalna pandemija Korona virusa (SARS Cov 2- Covid - 19) koja je prvi put u povijesti zahvatila cijelo čovječanstvo, a time i Hrvatsku pa i Dalmaciju, uz katastrofalne posljedice s aspekta zdravstvenog, a potom i cijelog sociogospodarskog života, uz značajne restrikcije u gospodarstvu te posebice putovanjima uključujući i turistička na globalnom planu. Sukladno temi ovog rada vrijedno je analizirati slične pojavnosti tijekom milenijske povijesti i njihov utjecaj na društvo te segmente razvoja zdravstvene i turističke kulture uključujući i putovanja kroz povijest analogna turističkim (predturistička) od antičkih vremena, do onih tretiranih „modernim" turizmom koja se odvijaju tijekom posljednja 2 stoljeća. Ova je tema danas izuzetno važna na globalnom planu, a posebice u gotovo 200 turističkih zemalja s više milijardi turista godišnje u svijetu. To uključuje i Hrvatsku koja svoj društveni i gospodarski razvoj umnogome temelji na direktnim i multiplikativnim učincima turizma što čine preko $20 \%$ BDP-a zemlje, uz značajan utjecaj na cjelovitu sociogospodarsku strukturu posebice Dalmacije, ali i Hrvatske u cjelini. Ne ulazeći u brojne teorijske rasprave javlja li se turizam kao društveni fenomen (Krapf, Hunziker, 1963), s počecima civilizacije u Starom vijeku ili pak industrijskog društva početkom 19. st. (Alfier, 1977), u ovom radu nastojimo obuhvatiti slijed globalnih pandemija i njihov utjecaj na životnu svakodnevicu čovječanstva. To posebno uključuje putovanja u okviru predturističke i turističke ere kroz logičan dijalektički pristup kojim se sve društvene pojavnosti prate od njihova začetka, rasta, stagnacije, pada i ponovnog uzleta. Ovo je sukladno znakovitoj Aristotelovoj sintagmi „svijet je vječita vatra koja se po mjeri pali $i$ po mjeri gasi", a na tragu Grčke antičke filozofske škole (Platon, Aristotel, Epikur...- IV. st. p.n.e), što Leine (1980) prenosi i na turizam izrijekom "jedina konstanta u turizmu je njegova 
neprestana mijena". Misli se pritom na kvantitativne, a potom i kvalitativne promjene koje svaki društveni fenomen pa i turistički oduvijek prate, uključujući i duže ili kraće prekide izazvane višom silom kojom tretiramo i aktualnu globalnu pandemiju. Ona je značajno poremetila sociogospodarske pa i turističke tijekove diljem svijeta, uz danas još nesagledive posljedice (Đikić, 2020) koje su na početku bile katastrofalne samo za izvorište u Wuhanu i okruženju, a potom u Europi posebice za Bergamo i sjever Italije. U početku drugog vala tijekom ljeta posljedice su već bile vrlo ozbiljne na svjetskoj razini, ali i za Hrvatsku pa i Dalmaciju s velikim odrazom na rezultate turističke sezone o kojoj hrvatsko, a posebice dalmatinsko gospodarstvo praktički ovisi. Zabrinutost za budućnost u nadolazećem hladnijem razdoblju godine kada su respiratorne bolesti i zaraze znatno učestalije, pokazala se opravdanom već od listopada 2020. g. Tada se bilježi iznimna progresija zaraze Korona virusom diljem svijeta, sa sve većim restrikcijama u putovanjima te ukupnom sociogospodarskom životu, uz intenziviranje napora zdravstveno epidemioloških institucija ka pronalaženju učinkovitih cjepiva te procjepljivanje pučanstva koje u Europi pa i Hrvatskoj ozbiljnije nastupa početkom 2021. s nadom suzbijanja pandemije do početka turističke sezone.

Tretirani prilog multidisciplinarnog karaktera metodološki se temelji na znanstveno komparativnoj metodi istraživanja povijesno kulturnog i turističkog kontinuiteta razvoja društva (historical desk research), s posebnim osvrtom na svjetski relevantnu regiju Dalmaciju. Polustoljetna praktična i znanstveno istraživačka aktivnost nositelja ovog rada u okviru kulturnih, turističkih, upravnih i visokoškolskih institucija uz studijska putovanja i komunikacije s eminentnim kulturnim i turističkim znanstvenicima i praktičarima diljem svijeta, rezultirali su s više desetaka objavljenih knjiga i znanstvenih radova u domaćim i inozemnim publikacijama, te omogućili komparativnu analizu u priloženoj literaturi elaboriranih povijesnih i aktualnih turističkih trendova, uz projekciju budućih kretanja i na polju interakcija kulture, zdravstvene kulture, pandemija i turizma.

\section{Zdravstvena kultura, pandemije i turistička te njima analogna putovanja u povijesnom kontekstu}

\subsection{Interakcije pandemija, zdravstvene kulture i putovanja u Starom, Srednjem i Novom vijeku}

Pojave lokalnih epidemija, a pogotovo globalnih pandemija oduvijek su kod ljudi izazivale strahove, zabrinutost pa i paniku. Prema mnogim istraživačima koje operacionalizira izraelski povjesničar Harari (2015), fenomen pandemija koincidira s pojavom sjedilačkog načina života koji zamjenjuje onaj čovjeka sakupljača i lovca grupiravši ga u sve veća naselja, a potom i gradove gdje se u dugo živi bez neophodne higijensko sanitarne i zdravstvene infrastrukture. Organizirane ljudske zajednice koje se javljaju već u četvrtom mileniju p.n.e. (Babilon...), rezultiraju uz razvitak gradova, trgovine i novca, sve intenzivnijim putovanjima motiviranih trgovanjem, religijskim i kulturološkim te zdravstvenim i ladanjskim potrebama, što dakako pogoduje širenju epidemija i pandemija. Već u trećem tisućljeću pisani izvori spominju posjete egipatskim piramidama u Gizahu i atrakcijama Babilona te velike religijske manifestacije u čast bogova i (ili) vladara rijekama Nil, Eufrat i Tigris... Slične pojavnosti imamo i na Dalekom istoku u kineskim i indijskim te japanskim visokim kulturama, posebice 
u porječju rijeka Jangcengjang te Ganges (Geić, 2002). Pandemijama su već u Starom vijeku pogodovala i relativno intenzivna putovanja naročito na prostoru Sredozemlja posebice u vrijeme Antike i Helenizma u Grčkoj te procvata Rimskog imperija. U ranim se fazama civilizacije rješenja za bolesti pa i epidemije te pandemije uglavnom pokušavaju naći u magijskim i skolastičko religijskim vjerovanjima, smatrajući da su ove kataklizme kazna čovjeku od strane svemogućih božanstava. U tom pravcu se razvijaju i različiti pravci magijskih i religijskih predstava i "terapija" u sferi primitivne zdravstvene kulture, u nadi božjeg oprosta te ozdravljenja i prestanka zaraza pa i pandemija, a božanstvima su podizani grandiozni spomenici te posebice u srednjem vijeku brojni sakralni objekti.

Zdravstvena kultura kao dio opće kulture, u najranijim poznatim civilizacijama Starog vijeka na prostorima Sredozemlja i Bliskog istoka, ali i Dalekog istoka (kineska alkemija, Hinduizam Indije, Sintuizam Japana..), sredinom prvog tisućljeća p.n.e. postupno iz sfere kultova, magije, vradžbina, alkemije i religije kao metoda pokušaja liječenja, postupno nakon 520. p.n.e. prelazi u okvire znanstveno utemeljene grčke helenske medicine, a grčki liječnici javljaju se na dvorovima antičkih vladara potiskujući postupno vračeve i opsjenare (Arsentijević, 1973). Njenim začetnikom smatra se liječnik i medicinski pisac Grk Hipokrat (460.380.p.n.e), uz preteče Demokeda i Onesila, naspram Orfičko-pitagorskog (Orfej i Pitagora) empiričkog magijsko religijskog pravca koji je prevladavao i u predantičkim civilizacijama dijeleći čovjeka na njegovu duhovnu i tjelesnu komponentu, a liječenje prakticirao na temelju terapija u kojima su uz molitve prevladavali ritam, glazba i ritualni iscrpljujući plesovi sve do stanja transa. Ovo se u praksi nakon pojave Hipokrata i njegove medicinske doktrine, postupno napušta, makar minorno egzistira čak i danas u tradicijama zabačenih plemenskih zajednica (Amazona, Afrika..), ali i šire, kroz termine tzv. narodne ili alternativne medicine koje se generacijama prenašaju s koljena na koljeno i u našim krajevima pa i Dalmaciji. Znanja Hipokratove helenske medicine kao i ostale segmente kulture pa i zdravstvene kulture ("u zdravom tijelu zdrav duh") osvajanjem Grčke preuzima i Rim, posebno poslije katastrofalne pandemije kuge 293. p.n.e., nakon koje se na temeljima Hipokratove medicinske škole osniva i prva rimska bolnica Insula Tiberini 291. g. p.n.e. po ugledu na helenske Jatrije, a za cara Konstantina Velikog u 4.st. poslije učestalih epidemija Lepre, u Rimu se osniva i prva bolnica za liječenje gubavaca. Sasvim je logično da u vremenima epidemija i pandemija koje su redovito harale i širile se izuzetnom brzinom posebice tijekom Starog i Srednjeg vijeka (lepra, kuga, malarija, difterija, dizenterija, boginje, tifus, tuberkuloza...), sukladno relativno intenzivnim putovanjima ( pogotovo diljem Sredozemlja) iz trgovačkih, religijskih, ratnih, kolonizatorskih te današnjim turističkim putovanjima analognih pojavnosti, to bio nepremostiv problem posebice u tadašnjim vremenima nedovoljno razvijenog zdravstva i zdravstvene kulture. Kroz povijest su najpoznatije i najsmrtonosnije bile epidemije lepre, te kuge koje su često prelazile i u globalne pandemije te zahvaćale i naše krajeve pa i Dalmaciju kao važan dio mediteranskog plovnog pravca.

Lepra (guba- Hansenova bolest) se kao kožna zarazna bolest spominje već u 6. st. p.n.e., a opisana je i u Starom zavjetu od Mojsija te u Bibliji. Oboljele liječi i Isus Krist, uz sv. Lazara zaštitnika od Lepre koji je i sam bio zaražen, odakle i potječe naziv karantenske institucije Lazaret. Uzročnik bolesti je bakterija "Microbacterium Leprae" koja dolazi iz Kine i Indije, te preko Babilona i Egipta stiže u Europu. Prvi europski lazaret otvoren je u Francuskoj već u 5. 
st., a u Dubrovniku 1272.g. kao prvi u Dalmaciji i Hrvatskoj, uz sklonište za gubavce 1306. te novi suvremeni lazaret od 1590.g .Tu su i značajne preventivne aktivnosti u Trogiru i Splitu koji su slijedom svojih razgranatih trgovačkih veza bili također izloženi zarazama uz organiziranje karantene (lazareta) na otoku Čiovo (samostan Sv. Lazara -1372.g.), gdje su pojedinačni recidivi ove bolesti bilježeni sve do sredine 20.st. Zadnji leprozorij na prostoru Dalmacije osnovan je u Metkoviću 1905., koji je zatvoren 1925., a u Grčkoj na otoku Spanalonga tek 1957. Unatoč antibioticima posljednjih desetljeća u svijetu je od lepre oboljelo preko 16 milijuna ljudi, a samo 2016. bilo je 200 tisuća novo oboljelih (www. wikipedia.org.).

Kuga, čiji je uzročnik Yersinia Pestis (štakorska buha) otkriven tek u 19. st., prema grčkom se povjesničaru Tukididu javlja u 5 st. p.n.e. pod nazivom Atenska kuga, koja se preko Dalmacije kao vjekovne komunikacije od istoka prema Europi, prenijela u Rimsko carstvo. Tu su se razvile poznate epidemije Antoninove (Galenove), Atenske, Rimske, Ciprijanove i Konstantinove (4.-3.st. p.n.e.) te Justinijanove kuge (5. st.), od kojih su oboljeli i umrli i brojni rimski te bizantski carevi. Prenaša se kapljičnim putem, a u novije vrijeme liječi se antibioticima. Izvorište je, najčešće kao i kod Lepre bilo na Dalekom istoku, a prijenosnici na čovjeka su bili glodavci. Iz Kine preko Indije zaraza se prenašala trgovinskim i drugim putovanjima te vojnim pokretima (Aleksandar Makedonski...) do Egipta i diljem Sredozemlja, a potom preko Rimskog imperija i širom Europe. No, prve manje poznate i dokumentirane pojave pandemija zabilježene su u Kini još u trećem tisućljeću p.n.e., s ogromnim, znanosti do danas nepoznatim žrtvama. Katastrofalne razmjere pokazuju procjene suvremenih istraživača da je tijekom povijesti od brojnih pandemija kuge umrlo preko pola milijarde ljudi ili 2/3 žitelja Europe, od čega samo u pandemiji Antoninske kuge (165.-180.g.) čak 1/5 rimskog carstva ili 7 milijuna ljudi. Istoj je slijedila Ciprijanova kuga od 250.-270.g. također s milijunskim žrtvama. Posebno pogubna je bila Justinijanova kuga (541.-542.g.) s gotovo 50 milijuna umrlih, a još strašnija kuga u 14. st.(„,crna smrt“), pomorila je preko 200 milijuna ili trećinu Europljana. Frapiraju i podatci da je od također katastrofalne pandemije velikih boginja samo 1520.g. umrlo 56 milijuna ljudi. Procjene su da je do 1978.g. kada je cijepljenjem kuga najvećim dijelom iskorijenjena (u Hrvatskoj 1972.), ova bolest koja je prepoznata već na mumiji egipatskog faraona Ramzesa V., pomorila između 350 do 500 milijuna ljudi uz konstataciju da je od te zarazne bolesti stradalo više ljudi nego u svim ratovima kroz povijest čovječanstva (Cvetnić, 2020). Radi usporedbe, broj mrtvih od kasnije pandemije Španjolske gripe (1918.-1919. g.). brojio je 100 milijuna ljudi, uz peterostruko više oboljelih. Tu su i Azijska gripa iz 1957./8. s milijun žrtava, te svinjska gripa s žarištem u Meksiku uz pola milijuna umrlih itd. (Meyer 1961, Cvetnić 2016). Povjesničari medicine i epidemiolozi računaju da je samo u Srednjem vijeku kroz 3 velika vala do od 6. do kraja 15. st. bilo u svijetu 109 epidemija kuge, a u Novom vijeku do 1720.g. još 45 (Cvetnić, 2016). No, ona se javlja i kasnije pa u 19.st. u Europu stiže iz Hong Konga harajući diljem Kine i Indije gdje se bilježe više milijuna žrtava (Meyer, 1961).

U Novom vijeku od ostalih, učestalih teških epidemija i pandemija koje su također $u$ nekim područjima (Jugoistočna Azija, Daleki istok te Bliski istok pa i Europa..), uz ostale životne tijekove ometale i turistički razvoj, treba navesti epidemije malarije u močvarnim područjima svijeta pa i Dalmaciji, te epidemije kolere u 19. st. Izvorište kolere je bilo u Indiji (1830-ih) u porječjima velikih rijeka (Ganges, Brahmaputra..), u kojem okruženju su higijensko sanitarni uvjeti te zdravstvena kultura bili izuzetno niski kroz povijest kao što je slučaj još i u današnje vrijeme. U 19. stoljeću obje ove zarazne bolesti šire se u znatnoj mjeri i u našim 
krajevima uključujući i Dalmaciju, uz remećenje životne svakodnevice pa i dinamike prvih suvremenih turističkih kretanja. Stoga se ovdje organiziraju nužne aktivnosti i institucije za njihovo suzbijanje, koje konačnim uspjehom rezultiraju tek početkom 20 stoljeća. Katastrofalne su procjene žrtava i za AIDS te ebolu, oko 40 milijuna (Cohen, 1998). One su, posebno u Africi, još uvijek aktivne kao i malarija, na što često upozorava WHO (Knez, 2020; Antić, 2020). Zanimljivo da je godine 1815. kuga (opet) zabilježena i u Dalmaciji (Makarska), a vjerojatno i šire, o čemu svjedoče Instrukcije vezane za kužne bolesti Pokrajinske vlade Kraljevine Dalmacije u Zadru (1814.). na talijanskom i dalmatinskom (pučko hrvatskom) jeziku vezano za kužne bolesti, čije je žarište bilo tih godina u Turskoj. Činjenica je da ni do danas ova opaka bolest, unatoč postojanja cjepiva i lijekova (antibiotici), nije definitivno iskorijenjena pa je pod nazivom Bubonska kuga bilježimo 2017.g. na Madagaskaru, a 2019.g. i u Mongoliji, nakon čega su zbog bojazni od njenog širenja, granice susjedne Rusije bile zatvorene.

\subsection{Pandemije, ladanjska kultura i ugostiteljstvo u predturističkoj eri}

Aktivnosti i kretanja ljudi analognih kasnijem turizmu (Cohen, 1998), inicirala su još u prvom mileniju prije Krista razvoj posebnih djelatnosti poput ugostiteljstva koje je nudilo usluge noćenja te prehrane i točenja pića za sve veći broj sudionika. Povijesni izvori spominju prve pojave pivnica, a potom i ostalih ugostiteljskih objekata u starom Egiptu te Bliskom, Srednjem i Dalekom istoku pa i diljem Sredozemlja, a na tragu tradicionalnog gostoprimstva kada je gost smatram božanskim bićem koga je trebalo poštivati i častiti, što je do danas sačuvano u nekim tradicionalnim pustinjskim plemenima Bliskog istoka (Beduini- Druzi...), a donedavno i u ruralnim prostorima Dalmacije. Prvi ugostiteljski objekti (pivnice) spominju se već u prvom mileniju p.n.e. u tekstovima na egipatskim papirusima vezano za religijske obrede i svečanosti te gozbe u kućama egipatske aristokracije (..."Uživajte jer život traje samo časak"..). Vino se posluživalo u domovima, ali i ugostiteljskim radnjama za bolje raspoloženje, no i kao svojevrstan ljekoviti (diuretik) te energetski napitak za pučanstvo i vojne postrojbe. U Kršćanstvu kao jednoj od tri monoteističke religije, glorificira se vino kao božji napitak koje se simbolično uspoređuje s krvlju (Isus Krist), a svećenstvo ga u vjerskim obredima koristi do današnjih vremena. Obzirom na raširenost Rimskog carstva diljem Europe i Sredozemlja uz razvijenu putnu mrežu slijedom vojnih a potom i trgovačko gospodarskih razloga, egzistirali su i različiti objekti ugostiteljskog karaktera. Njih nalazimo u gradovima ili čvorištima puteva te uz javna kupatila, cirkuse i hramove pod različitim nazivima. Za smještaj i prehranu stranaca brinula se država preko posebnih svratišta uz pločicu-dokument (,tessera hospitalis") odakle kasniji izraz „hospitium" (gostionica s prenoćištem). Za državne službenike i vojnike na određenim udaljenostima podizani su posebni objekti s kompletnom ugostiteljskom uslugom, a za posebno visoke goste i raskošna prenoćišta „praetoria“ ili „palatia“ (Vujević, 1997.). I u našim krajevima u doba Rima bilo je postaja za noćenje i ugostiteljske usluge posebice na glavnim prometnicama te uz ljekovita vrela, terme, toplice i kupališta (Aquae Balisae -Daruvar, Aqua viva-Varaždin, te u Dalmaciji Aequum kod Sinja...). Najraširenija ugostiteljska radnja na prometnicama i u gradovima bila je "taberna" s ponudom vina ( u Dalmaciji „tovirna"). Ova putovanja i okupljanja te manifestacije u Starom vijeku, uključujući i predturistička putovanja analogna današnjem turizmu i njegovim selektivnim oblicima, bivaju kao i ostale aktivnosti za vrijeme pandemija na duža razdoblja prekidana zbog opasnosti prijenosa zaraza i 
primarne brige za zdravlje pa i opstanak pučanstva. Već antička dostignuća u sferi zdravstvene kulture i medicine nametala su potrebe izolacija, karantena te uvođenja sve strožih mjera u sferi higijensko sanitarne prevencije. To je bilo evidentno posebice u prostoru Rimskog carstva, a prvenstveno u gradu Rimu gdje se grade velike terme za povlaštene pa $\mathrm{i}$ rimsko građanstvo, akvadukti, kanalizacijski sustavi, javna kupališta i za niže slojeve i sl. Štoviše pripadnici povlaštenih klasa na tom tragu grade diljem carstva vlastite terme (Posejdonove na otoku Ishiji, Dioklecijanova palača kao sumporne i morske toplice u Dalmaciji....), palače i ljetnikovce te ladanjsko gospodarske vile rustike u atraktivnoj prirodi izvan gradova, a najčešće uz more uključivši cijelo istočno jadransko priobalje. Posjećuju se redovito i javni lokaliteti termalnih ljekovitih izvora i kupališta sukladno sintagmi „salus per aquam" (vodom do zdravlja), koji se podižu diljem Carstva, a čiji su ostaci vidljivi i u brojnim današnjim poznatim termalnim lječilištima Europe i Sredozemlja (u Vichiyu, Aex-les Bainsu...) pa i u prostorima današnje Hrvatske (Marković, Marković, 1966.). Ova se lječilišta tijekom Srednjeg vijeka slijedom religijskih dogmi sustavno razaraju i napuštaju, da bi se u Novom vijeku, a posebice u turističkoj eri pojavom zdravstvenog turizma i rastom zdravstvene kulture obnavljale, pružajući blagotvorne učinke termalnih i mineralnih vrela, mora i sl. U iznijetom kontekstu, a temeljem vjekovnih tradicija u Europi danas bilježimo preko tisuću toplica odnosno hidrotermalnih lječilišnih mjesta, od čega je 1/3 u Njemačkoj (340), u Francuskoj 98, Sloveniji 86, itd. U Hrvatskoj imamo službeno proglašenih 30- tak ljekovitih mjesta, no samo 16 verificiranih lječilišta. Od spomenutog broja je polovica na Jadranu (u Dalmaciji 7), a ostale u unutrašnjosti koje umnogome doprinose razvitku zdravstvenog turizma Hrvatske. Ipak on još ni dijelom ne koristi sve prirodne potencijale (cca 250 ljekovitih lokaliteta) i rastuću potražnju za ovim visoko profitabilnim selektivnim oblikom turizma (Pančić - Kombol, 2000; Geić, 2011).

\section{Epidemije, pandemije i zdravstvena kultura kroz povijest Dalmacije}

\subsection{Pojave i posljedice pandemija u Dalmaciji u Starom i Srednjem vijeku}

U kontekstu čestih pandemija koje su od pamtivijeka prijetile čovječanstvu pa i našim krajevima, ljudi su se nastojali štititi sukladno civilizacijskim dostignućima medicine u odgovarajućem vremenu i prostorima. Stoga je sasvim je logično da se duge tradicije empiričkomagijske, Orfičko pitagorske, te kasnije znanstveno utemeljene Hipokratove grčke, a potom i rimske zdravstvene kulture te medicine prenašaju migracijama i kolonizacijama na prostor Ilirika, a prvenstveno u Dalmaciju. Oni ipak u kasnijem dugom povijesnom razdoblju, pored doktrine Hipokrata još dugo njeguju štovanje i religijsko magijske rituale u slavu grčkog Asklepa, a kasnije i rimskog božanstva lječništva i zaštitnika ljekara i ljekarnika Eskalupa. Njih prihvaćaju i Iliri, uz zadržavanje autohtone lokalne tradicije narodne „medicine“. Ona je bila zasnovana na ljekovitosti prirodnih supstanci mediteranskog aromatskog bilja, termalno mineralnih voda, mora i sl. koje su elemente posebice kroz SPA kulturu Rimljani znatno unaprijedili te proširili diljem Carstva pa i u Dalmaciji. Inače Dalmaciju u kontekstu epidemija zaraznih bolesti prvi spominje grčki povjesničar Tukidid već u 5.st. p.n.e., kada bilježi pojavu Atenske kuge. Po njemu ona slijedom kolonizatorskih migracija iz Grčke upravo preko Dalmacije stiže u Rim pri čemu on kao kobne još bilježi i epidemije boginja te tifusa. U Dalmaciji su se dugo zadržali i grčko rimski kultovi božanstava Silvana i Ninfe, zaštitnika voda, šuma 
(prirode), ali i zdravlja, te bog vina i veselja Bakho (Bakus), odnosno rimski Dionizije. Vino je tada pa i kasnije smatrano ljekovitim napitkom za oporavak organizma te diuretik, a Hipokrat grožđe koristi i za liječenje ženskih bolesti (TV Nova, 13.09.20.). Važna je bila i božica zemlje Kybela (Magna mater) koja je štitila od potresa vrlo učestalih u Dalmaciji, nakon kojih su kao i kod ratova, izbijale katastrofalne epidemije (Babić, 1984). Materijalni spomenički artefakti ovih kultova vrlo su česti u arheološkim nalazima diljem Dalmacije (Trogir, Split...), kao i pojavnosti u sferi nematerijalne baštine (vinske svečanosti -„Bakovo“...), a i danas u dalmatinskim napjevima nalazimo česti izraz "zemlja mater", što sve može biti autentičan dio ponude suvremenog kulturološkog pa i zdravstvenog turizma. Već Plinije u I. stoljeću (48.g. nove ere) piše o ljekovitosti dalmatinskog aromatičnog bilja koje se slijedom medicinskih potreba, uz crno vino iz llirika kao cijenjeni diuretik, izvozi u Rim što potvrđuje i njegov navod : "Materia medica antičke medicine i farmacije obogaćena je biljkama s istočne obale Jadrana". Tekovine kulture pa i zdravstvene kulture s učilišta Monte Casina i Salerna, a potom za vrijeme Venecije naprednijih medicinskih i drugih studija Bolonje, Pavie i Padove, prenašahu se po logici stvari na Istočni Jadran, a preko njega i duboko u balkansku unutrašnjost (Bazala, 1973). To je posebno evidentno u vrijeme vladavine Mletačke republike istočnim Jadranom (14.-18. st), kada su sinovi dalmatinskog plemstva svoju izobrazbu gradili upravo na tim učilištima. U kontekstu naše teme posebno treba apostrofirati medicinske i farmakološke studije u Padovi, s kojeg sveučilišta u dalmatinske gradove dolaze vrsni liječnici i ljekarnici već od 13. st. na ovamo, uz velike zasluge na razvoju zdravstva, ljekarništva te uopće zdravstvene kulture (Tartalja, 1971). U kontekstu kontinuiteta zdravstvene kulture Rimsko carstvo tijekom Starog vijeka i u Dalmaciji podiže brojne rimske vile rustike za povlaštene političke uglednike i njihove goste, ali i razvojačene zaslužne legionare ("Claudie pea fidelis" 41-54 g.). Njihove arheološke ostatke nalazimo u klimatski i pedološki pitomom podneblju Istre i Dalmacije, a posebno Salonitanskog agera i obližnjim otocima (Babić, 1984). One, uz Dioklecijanovu palaču, mogu biti dokaz turizmu analognih pojavnosti već u antičkim vremenima Starog vijeka. Jedan od najstarijih dalmatinskih pokretnih spomenika vezanih za medicinu ranog Srednjeg vijeka je olovna ploča "Tabella plumbea“ iz 6. st. nađena u Trogirskom velom polju na kojoj je natpis s izmiješanim poganskim i kršćanskim elementima u svrhu zaštite puka od uroka (bolesti), u skladu s magično teurgičnim vjerovanjem pa i medicinom toga vremena, koje se pojave javljaju i na drugim područjima Mediterana još u Antici (Il. st.). Naime, razvojem Kršćanstva i slijedom prevlasti crkvenih religijskih dogmi i misticizma tijekom Srednjeg vijeka i u Dalmaciji se reafirmira već u Antici gotovo prevladani religijsko magijski dogmatski skolastički pogled na svijet koji uz opće kulturno i intelektualno nazadovanje vraća orijentaciju pučanstva prema svecima zaštitnicima od pojedinih bolesti pa i pandemija. To potvrđuje i natpis na nadvratniku srednjovjekovne crkvice sv. Jurja (11.st.) u Žestinju (Kaštela) „Ovdje će umorni naći počinak, a bolesni zdravlje" (Glasinger, 1971). Česte migracije i putovanja su dakako pogodovale učestalim pojavama zaraza i pandemija posebno u Dalmaciji koja je svojim morskim i kopnenim komunikacijama milenijima bila razmeđe kultura i civilizacija Istoka i Zapada. Posebice je pogubna bila kuga za vrijeme bizantskog cara Justinijana od 541.-542. g. Ona je prema povjesničaru Prokopiju usmrtila $40 \%$ Carigrada i $25 \%$ pučanstva Bizanta koji je zahvaćao i dalmatinske gradove s okruženjem te se ponavljala u više navrata do 750 . g., a onda eruptirala od 11. do 14. st. pa i kasnije. Logično su epidemije i pandemije, posebice kuge, kao posljedica razgranate trgovine i putovanja diljem Bizantskog carstva, najprije 
zahvaćale upravo dalmatinske gradove. Oni su uživali komunalnu autonomiju, no stvarno bili (osim Dubrovnika) pod jurisdikcijom Bizanta (od 6.-9.st), a potom hrvatskih narodnih vladara (9.do 11.st.), Ugarsko hrvatske države (11.-15.st.), te od 15. do kraja 18. st. Venecije, Francuza (početak 19.st.) i Austrije (1814-1918.), s razgranatim trgovačkim i kulturnim vezama i putovanjima diljem Sredozemlja i unutrašnjosti Balkana te duboko u srce Europe, a otkrićem Novog svijeta i znatno šire u prekomorske zemlje. To je bilo evidentno posebno u Dubrovačkoj republici, kao važnom pomorskom i trgovačkom centru Dalmacije i Mediterana, gdje se kuga javlja već 901. g. te 1145. g., a ponavlja u više navrata između 1348.-1360.g., nakon koje je grad ostao na svega trećinu stanovnika. To je bio razlog otvaranja i prve dubrovačke karantene u našim krajevima već 1272. g. (Ravančić, 2006) , te potom skloništa za gubavce 1306. i lazareta 1590. Radi zaštite puka od 1301.g. u gradu postoji organizirana liječnička služba, od 1317.g. ljekarna, a od 1347. i bolnica. Inače o višestoljetnoj izloženosti naših krajeva ovom pošasti govori i podatak da je zadnja epidemija kuge zabilježena u Dubrovniku još 1815.g. Ni Zadar nije bio pošteđen zaraza posebice u vrijeme križarskih vojni (11.-13. st.), kada je grad bio važna luka na putu u Svetu zemlju. Ovdje kuga hara 1034.g. a ponovo se javlja kao i susjednom Šibeniku u više navrata tijekom 14. i 15. st. pa i kasnije, uz svjedočanstva kako je zbog velikog broja preminulih bilo nemoguće funkcioniranje gradskog vijeća. Naime, od 1348. - 1784.g. kuga se čak u desetak navrata javlja u Dalmaciji , da bi pomorila gotovo $70 \%$ stanovnika Splita koji u namjeri suzbijana zaraze 1529. otvara Lazaret tada najsuvremeniji u Dalmaciji. Razmjere pošasti govori i podatak da je slijedom pandemije i stalne turske opasnosti ovaj grad s preko 5000 stanovnika tijekom 15. i 16. st. bio sveden na svega 1600 ljudi (Kečkemet, 1973). Kuga se od 13. do 14. st. javlja i u Trogiru te je vjerojatno osim Mongola koji su progonili Ugarsko hrvatskog kralja Belu, a po nekim istraživačima i prenosili kugu, bila uzrokom njegova sklanjanja u Trogir, a potom na čiovski otočić (Kraljevac) u blizinu benediktinskih postaja i samostana, vjerojatno i radi svojevrsne karantene i liječenja. Zaraza je od 1344.-1348.g. još snažnije poharala Trogir gdje je kao i u cijeloj Europi pomorila gotovo 2/3 pučanstva nakon koje Trogirani grade zavjetnu crkvicu sv. Eustahija na Krbanu. Očigledno se ova epidemija javila i 1419.-1420.g., kada je većina trogirskog plemstva izbjegla u tada sigurniji Split, o čemu govori poziv Gradskog vijeća da se vrate kako bi branili grad od Mlečana. Ona se javlja ponovo u četiri vala od 1429.-1466. , kada je pokosila preko 2000 građana da bi preostala manjina podigla još dvije crkve svecima zaštitnicima od kuge; Sv. Sebastijana na trgu, a nakon epidemije 1525. i crkvicu sv. Roka na obali, što je bilo uobičajeno i u drugim dalmatinskim gradovima (Delalle, 1936).

Tijekom proteklog srednjovjekovnog razdoblja izolacija malih feudalnih gradova-državica, česti ratovi i nemiri te nesigurnost putovanja, odveli su Europu u sveopće nazadovanje većine stanovništva, što je po logici stvari snižavalo nivo zdravstvene kulture i infrastrukture, uz česte epidemije i pandemije. $U$ okruženju opasnosti od zaraza i čestih pandemija u srednjem vijeku i putovanja su logično bila ograničena s izuzetkom od crkve organiziranih hodočašća. Zdravstvena kultura bila je svedena na razinu koju je određivao kler uz zabranu kupanja i uopće rekreacije na moru te u toplicama i termama koje su sustavno devastirane. Ipak i u krilu ovih retrogradnih nazora srednjovjekovne crkve, u okviru Kršćanstva javljali su se i napredniji redovi poput Benediktinaca, Dominikanaca te Franjevaca koji se uz svoje osnovno religijsko poslanje bave i liječenjem na bazi prirodnih supstanci, koristeći pritom iskustva antičke grčko rimske pa i orijentalne zdravstvene kulture i medicine. Od 11. do 13. stoljeća Europa i Bliski 
istok poprište su Križarskih ratova, a nakon toga u 16. st. i velikih sukoba Venecije i Osmanlija za prevlast na Mediteranu (Kandijski i Morejski rat...), u kojima su involvirani i jadranski pa i dalmatinski gradovi kao križarske luke), ili pak direktni sudionici ustupanjem naoružanih galija s posadama u ratovima na strani Venecije. Križarski ratovi izazivaju velike migracije pučanstva diljem Europe i Bliskog istoka, što uz inače niske standarde zdravstvene kulture logično pogoduju prijenosu i razvoju zaraza pa i pandemija koje su zahvaćale cijelu Europu i šire okruženje. Posebno su fatalne bile epidemije kuge u 13. i 14. stoljeću kada su pomorile preko pola pučanstva Europe, a zahvaćale su gotovo svaku generaciju sve do 17. st. (Russell, 1966). Zbog nepoznavanja uzročnika oboljenja i nemoći tadašnje medicine da suzbije pandemije zaraznih bolesti koje su harale i Dalmacijom, pučanstvo je podiglo brojne zavjetne crkve i kapelice svecima zaštitnicima pojedinih bolesti koje se danas mogu revitalizirati kroz itinerare kulturološkog pa i zdravstvenog turizma. Sve učestalije zaraze i pandemije koje su remetile normalan društveni i gospodarski razvitak inače prosperitetnih srednjovjekovnih dalmatinskih gradova-komuna, bile su poticaj naporima jačanja higijensko sanitarnih i zdravstvenih službi što je regulirano i u gradskim statutima već od 13.st. Oni su određivali pravila ponašanja građana te financiranje liječničkih i ljekarničkih službi s najstarijim ljekarnama na Balkanu (Trogir 1271...). Ujedno su određivale mjere izolacija i karantena posebice glede čestih epidemija lepre (gube) te kuge. U kasnom srednjem vijeku u dalmatinskim komunama znalo je djelovati i po nekoliko ljekarni, te više gradskih liječnika mahom talijanskih korijena koji bez posebnih dozvola nisu smjeli napuštati mjesto boravka, a od kojih su mnogi bili žrtve pandemija kao najizloženiji dio pučanstva (Tartalja, 1971). Prvi leprozariji (lazareti) te karantene u Dalmaciji organizirani su bili u Dubrovniku (1272. 1306. i 1509.g.) te Trogiru (1372.) i Splitu (1590.). Za karantene je bio izuzetno pogodan otok Čiovo u vlasništvu komuna Trogira i Splita, na kome je po odluci Trogirskog gradskog vijeća iz 1357. bilo zabranjeno stanovati svima osim pustinjacima, eremitima i gubavcima. Oni su na otoku bili izolirani zasigurno i znatno ranije, vjerojatno već od rimskih vremena kada je Čiovo bila i kaznionica za protivnike rimske vlasti te heretika, a lepra bila već raširena u Rimskom carstvu pa i u Dalmaciji.

\subsection{Zdravstvena i ladanjska kultura Dalmacije te pandemije u Novom vijeku}

Sve veća kretanja ljudi u kasnom Srednjem vijeku dovela su do susreta i razmjena kultura različitih naroda pa i civilizacija te postupnog oslobođenja čovjeka od okova jednoumlja duhovnih autoriteta, uz postupnu reafirmaciju napuštenih tradicijskih vrednota i kulture pa i zdravstvene kulture dosegnutih još u antičkom razdoblju, što je evidentno i u dalmatinskim gradovima. To u potpunosti od 14. i 15. st. afirmiraju novi pokreti humanizma i renesanse u okviru intelektualnih i umjetničkih krugova, što uz senzacionalna geografska otkrića novog svijeta najavljuje i početak Novog vijeka (Marasović, 2001). Umjetnička i intelektualna elita svoje inspiracije, ugodu i zdravlje sve više nalazi otkrivanjem vrjednota prirode, ali i prirodnih zakonitosti te ljekovitosti voda, mora, flore i faune u okviru kojih resursa se razvija farmakologija i novi postupci u liječenju te medicinskoj preventivi i rehabilitaciji. Na tragu ushita prirodom i njenim ljepotama antičkog rimskog pjesnika Virgilija (70.-19.g. p.n.e.), inspiraciju u prirodi nalaze i slobodoumni literate Humanizma (Dante, Boccaccio, Petrarca...), pa i velikani Renesanse Leonardo, Rafaelo te posebice Mikelanđelo koji ushićen prirodom ustvrđuje: "Ni najveće umjetničko djelo nije ni sjena onoga što je stvorila priroda." Novi intelektualni pokreti 
slijedom antičkih znanosti i tradicija glorificiraju prirodu, kulturu i umjetničko stvaranje te odmor u prirodi, uključujući i segment zdravlja i zdravstvene kulture te rekuperaciju duha i tijela kroz učestala kretanja i putovanja izvan domicila. To je bilo i na tragu velikog humaniste i literata E. Roterdamskog ( 1469.-1536.), te nešto kasnije i francuskog putopisca M. Montagnea ( 1533.-1592.), autora djela "Journal de Vojages", obveznu literaturu tadašnje intelektualne elite. Ovim kretanjima svjedoči i činjenica da početkom Novog vijeka dalmatinsko, a posebice dubrovačko plemstvo i kler intenzivno grade svoje dvorove i ljetnikovce, te postupno sele izvan obzidanih gradova uzduž dalmatinske obale i otoka. Na tragu novih humanističkih ideja su bili i kasnogotički te renesansni umjetnici Dalmacije domaćih korijena ili importirani iz talijanskih i drugih mediteranskih kulturnih sredina. Kraj Srednjeg i početak Novog vijeka vrijeme je kada umjetnička elita ali i drugi visoko obrazovani Europljani ponovo nakon antike otkrivaju blagodati ladanja u blagoj mediteranskoj klimi, što su poslije antičkih vremena prve naznake oživljavanja predturističke, a od sredine 19. st. i turističke ere. Nakon Erazma Roterdamskog te M. Montaignea i drugih koji u 16. st. filozofskim djelima odnosno putopisima otkrivaju visoke kulturne vrijednosti i prirodne ljepote Europe, zdravstvene blagodati rekreacije u prirodnom okruženju u 17. st., afirmira i francuski književnik romantizma te prirodoslovac J.J. Rousseau poznatom izrijekom „Retour a la nature". To je potaklo brojnu intelektualnu elitu u otkrivanju atrakcija Alpa, kao najvećeg prirodnog čuda Europe, te Mediteranskog priobalja i zaleđa, posebice Toskane, Provanse, Atike, Katalonije pa i Istre te Dalmacije. Ove i druge atraktivne mediteranske regije postaju idealan prostor uživanja i psihofizičke rekreacije pa i liječenja uključivši tadašnju pošast tuberkuloze koja se lakše liječila u čistom planinskom zraku te ljekovitoj blagoj mediteranskoj klimi (Alfier, 1994). Na tom tragu su i poklonici naprednih ideja Francuske revolucije, Prosvjetiteljstva te Fiziokratskog pokreta koji od 18. st. sustavno istražuju prirodu. Oni u vrijeme francuske vlasti u Napoleonovim Ilirskim provincijama početkom 19.st., potiču modernizaciju poljoprivrede i šumarstva, osnivajući i u Dalmaciji tzv. „Agrarne akademije“ koje prosvjetljavaju pučanstvo u poljoprivredi, gospodarstvu, ali i zdravstvu i zdravstvenoj kulturi (Babić, 1987). To podrazumijeva i napredak u korištenju te preradi ljekovitog samoniklog bilja kojim je ovo podneblje izuzetno bogato, $\mathrm{s}$ tradicijom upotrebe u medicinske i prehrambene svrhe od antičkih vremena. Već Hipokrat u ovom kontekstu dva i pol milenija ranije konstatira kako se liječnici pa i narod, umjesto magijama u treba okrenuti vlastitom " dvorištu" tj. prirodi koja nudi ogromne potencijale ljekovitosti. Ove predaje i tradicije u Novom vijeku koriste i dalmatinski ljekarnici te farmakolozi od kojih se ističu Šibenčanin R. Visiani (1797.-1878.) profesor na Sveučilištu u Padovi i Trogiranin A. Andrić ( 1799.-1897.), koji sakupljaju i analiziraju ljekovito bilje ovog podneblja prerađujući ga u lijekove i proizvode za farmaceutsku industriju što se na toj bazi počinje intenzivno razvijati. Samoniklo dalmatinsko bilje bilo je od pamtivijeka važan dio prehrambenog lanca, na tragu Hipokratove sintagme: „Neka tvoja hrana bude lijek, a tvoj lijek bude tvoja hrana“. U tom je kontekstu početkom novog milenija i WHO je proglasila te preporučila mediteransku, a time i dalmatinsku prehranu kao najzdraviju, da bi je UNESCO potom uvrstio i u registar nematerijalne baštine čovječanstva. To se posljednjih godina nastoji operacionalizirati i u suvremenoj hrvatskoj, a posebice dalmatinskoj gastronomiji kao autohtonog dijela njene ugostiteljsko turističke ponude. Boravak u ljekovitom mediteranskom okruženju što ga pruža kombinacija mora, morskog aerosola, ljekovitog bilja te uopće primorske vegetacije, uz ljekovitu klimu te atraktivno podneblje i bogatu kulturno povijesnu 
baštinu, dovodi od sredine 19. st. do sve intenzivnijeg razvoja kulturnog te pogotovo zdravstvenog turizma na Jadranu pa i Dalmaciji. To je bilo posebice izraženo za indikacije bolesti dišnih organa, kardiovaskularnog i neurovegetativnog sustava, kožnih te reumatskih i drugih bolesti. One se i danas uspješno liječe u dalmatinskim specijaliziranim lječilištima, ali i samim turističkim boravkom u ekološki čistoj i zdravoj prirodnoj sredini dalmatinskog priobalja, otoka i zaleđa (Geić, 2012).

U 18. st. za Dalmaciju i promidžbu njenih turističko kulturnih te prirodnih vrednota, tradicija, načina života pa i zdravstvene kulture važan je putopis Talijana Alberta Fortisa "Viaggio in Dalmazia" (1774), objavljen nakon sličnih impresija o Dalmaciji Engleza Whellera i Spoona (1682) te Škota Adama i Francuza Clerisseaua (1764). Njima slijede putopisna izdanja francuskih putopisaca Cassasa i Lavalea (1782) itd. U 19. st. bilježimo slična djela brojnih drugih europskih putopisaca, ali i visokih dužnosnika te političkih i kulturnih uglednika koji svijetu otkrivaju „zaboravljenu "Dalmaciju (,terra incognita") i njene iznimne prirodne i kulturne vrednote što čine temelj njene turistifikacije od sredine 19. st. Oni poput Baurona (1888) s neskrivenim ushićenjem pišu o ovom u europskim krugovima dugo zapostavljenom, a iznimno vrijednom prostoru europskog juga riječima: „Salonitanski ager je vrt, plodna rivijera $i$ najugodnije podneblje Dalmacije". Od dalmatinskih otoka s kulturno povijesnog te zdravstvenog aspekta koji su u počecima suvremenog turizma pa i danas važan dio turističke zdravstveno kulturološke ponude, treba posebno istaknuti potencijale otoka Korčule te Hvara koji je zbog ljekovitosti svog podneblja dobio epitet dalmatinske Madeire na atraktivnom Azorskom otočju iznimno pogodnih klimatskih uvjeta, gdje tijekom 18. i 19. stoljeća dugo borave i liječe se najviši krugovi europske aristokracije posebice od tuberkuloze .

\subsection{Početci kulturnog i zdravstveno rekreativnog turizma te pandemije u Dalmaciji}

Uz opise bogate kulturne i prirodne baštine Dalmacije od strane europskih putopisaca, povjesničara te drugih znanstvenika i uglednih državnika kao preteča ovdašnjeg kulturnog ali i zdravstveno rekreativnog turizma, zanimljiva je njihova zadivljenost prirodom, lokalnom spomeničkom baštinom i autohtonim folklorom i etnografijom, uz isticanje stasitosti i ljepote dalmatinskih ljudi te enogastronomskih delicija (Duringsfel, 1857). To uključuje i opise kulture ugošćivanja kaštelanske plemičke obitelji Cambi, što je zanimljivo za povijest dalmatinskog ugostiteljstva. Posebno impresionira konstatacija saskog kralja Augusta II. nakon posjeta Trogiru i Kaštelima 1839. „...“Ova rivijera može se mjeriti s najljepšima u Europi... "(Geić, 1981; Piplović, 1997). Na tragu spomenutih posjeta i svjedočanstava koji su imali odjeka u europskim medijima, snažno raste interes austrijskih vlasti koja u tadašnjoj Kraljevini Dalmaciji poduzima značajne korake u izgradnji cestovne i lučke infrastrukture, a posebice obnovi i zaštiti kulturno povijesne i prirodne baštine kao temelja budućeg turističkog razvoja. To u konačnici rezultira rastom standarda pa i zdravstvene kulture ovog prostora. Početkom 20. st. o kulturnim i prirodnim vrednotama Dalmacije očituju se i svjetski nobelovci Herman Bahr (1909.- 1934.), Anatole France (1884.-1924.) te Bernard Shaw (1850.-1950.), a tijekom 20. i 21. st. ekspanzijom dalmatinskog turizma i cijela plejada najvećih svjetskih uglednika iz svijeta prirode, kulture, biznisa, filmske i modne industrije te politike, koji redovito posjećuju ovu turističku regiju. Potrebno je istači da turistička valorizacija ovog podneblja 
od sredine 19. st. počinje najprije kroz segment kulturnog te posebice zdravstvenog turizma, uključujući i vrijeme pošasti tuberkuloze diljem Europe, kao i drugih bolesti koje se tada nastoje liječiti ili prevenirati u klimatski poštednom i zdravom mediteranskom priobalju. 0 tome svjedoče i nazivi prvih društvenih organizacija u turizmu te njihovi statuti i pravilnici koji potenciraju kulturu te odmor i liječenje u ljekovitoj klimi i podneblju atraktivne jadranske pa i dalmatinske obale i otoka (Higijeničko društvo u Hvaru - 1868. i dr.). Spomenuti procesi, organizacijski i marketinški adekvatno praćeni bili su predznak kasnijih sve intenzivnijih turističkih privremenih migracija koje svojom masovnošću kulminiraju u 20. i 21. st. u okviru tzv. turističke ere. One danas u suvremenom održivom turizmu zahvaćaju gotovo pola čovječanstva u tijekovima domaćeg i međunarodnog turizma koji postupno iz luksuzne postaje egzistencijalna potreba suvremenog čovjeka. Na tom tragu se prema listi 20 vodećih turističkih zemalja svijeta posljednjih godina približava i Hrvatska s Dalmacijom kao vodećom turističkom regijom koja realizira oko $50 \%$ svih turističkih agregata $\mathrm{RH}, \mathrm{tj}$. preko pola milijuna turističkih kreveta i cca 50 milijuna noćenja (2019.g.) pretežno inozemne provenijencije (DZS $\mathrm{RH}, 2020$.), uz posjedovanje iznimnih budućih potencijala na svom priobalju otocima i zaleđu. Oni omogućavaju razvitak različitih selektivnih oblika turizma uključujući posebice cjelogodišnji kulturni te zdravstveno rekreativni, eko i ruralni turizam tijekom cijele godine, na čemu sustavno radi turistička organizacija. Od pandemija koje su remetile ravnomjeran sociogospodarski, a time i turistički razvoj Dalmacije tijekom 19. i 20. st. treba istaći tuberkulozu, malariju, koleru te španjolsku gripu koje su se povremeno javljale sve do prve trećine 20. st. Tuberkuloza se kroz povijest javlja već u Antici (460. g.) te se tretira kao teško oboljenje, da bi ekspandirala u 19 st. razvojem industrije i gradova uz velika zagađenja zraka te nizak životni standard doseljenog pauperiziranog pučanstva, naseljenog u siromašnim gradskim četvrtima. Rezultat ovih društvenih procesa i čestih epidemija te pandemija ogleda se u činjenici da je primjerice u tom vremenu čak 1,7 milijuna ili $25 \%$ umrlih Europljana bilo samo od posljedica zaraze tuberkulozom (kod nas "grudobolja“), uz 10 milijuna oboljelih. To stanje je umnogome poboljšano tek izumom penicilina u 20. st. te razvojem medicine, zdravstvene kulture i sustava javnog zdravstva koji propagiraju te postupno uvode organiziranu provedbu higijensko epidemioloških mjera, uz sve češće korištenje prirodnih čimbenika u prevenciji, liječenju i rehabilitaciji. $U$ to se uklapaju i sve razvijenije forme masovnih, a potom i održivih oblika putovanja ka moru, jezerima i planinama koje programe osigurava selektivni turizam i njegova infra i supra struktura. Kolera kao opasna zarazna bolest kojom se početkom 19. st. suočila i Dalmacija javlja se prvi put 1816. g. na indijskom potkontinentu s žarištem oko rijeke Ganges te se u sedam pandemija širi po Aziji i Europi. Hindusi i Muslimani koji su bili u njenom žarištu, a i danas su posebno ugroženi korištenjem zagađene vode i niskim higijensko epidemiološkim standardom, u nadi spasenja časte božicu Olidavi sve do današnjih dana. U svrhu zaštite pučanstva od epidemije kolere koja je zahvatila i Dalmaciju zanimljiva je preporuka dalmatinskih vlasti iz 1836. u kojoj se nalažu stroge sanitarno epidemiološke mjere što su relativno brzo urodile plodom. To je posebno važno i u kontekstu činjenice da se upravo nakon tih godina Dalmacija kao dio "K und K" monarhije nastoji Europi i marketinški predstaviti kao atraktivna nova destinacija pogodna za razvoj zdravstvenog, kulturnog i drugih oblika turizma i (Izložbe u Parizu i Beču i sl....). Malarija je u Dalmaciji kao i diljem svijeta kroz povijest također bila vrlo učestala zarazna bolest koja je prisutna među ljudima već 50 tisuća godina, a poznata je dugo i u drugim našim krajevima gdje je iskorijenjena tek 
30.tih godina 20. st. No, unatoč pronalaska lijekova (kinin i dr.), ona je još aktivna i u Europi (Albanija, Grčka, Južna Italija), posebice u močvarnim područjima. Uzročnik je parazit Plasmodium koga prenaša ženka komarca kojoj pogoduju tropski te suptropski močvarni i poplavni krajevi, uz procjenu epidemiologa od čak milijun žrtava godišnje u velikim epidemijama te izrazito veliku smrtnost oboljelih, nekada i do 80\% (Dauernbauer, 2013). U Hrvatskoj pa i Dalmaciji su poznata žarišta bila u prostorima nekadašnjih i/ili današnjih solana (Pag, Solin, Nin, Ston, Trogir.... ). U Trogiru je zbog močvarnog područja oko obzidane gradske jezgre ona poprimala epidemijske razmjere i bila pogubna kroz stoljeća, uz stacionar za oboljele u franjevačkom samostanu sv. Križa na Čiovu. Iz tog razloga u gradu je 1922. bio osnovan Antimalarični institut Kraljevine Jugoslavije koji je doprinio da se ova bolest konačno iskorijeni 1931.g. u Trogiru, ali i diljem Dalmacije. Ovome je znatno ranije tj. početkom 19. st. pridonijela i opsežna akcija tadašnje francuske uprave pod vodstvom Maršala Marmonta kao vojnog, te farmakologa Vicenza Dandola civilnog upravitelja. Ona je rezultirala uklanjanjem srednjovjekovnih gradskih zidina, isušivanjem močvara i zasađivanjem parkova oko gradova, što je znatno unaprijedilo higijensko sanitarne uvjete života kao prevenciji mogućih zaraznih bolesti diljem Dalmacije. U narednim decenijama u Kraljevini Dalmaciji infrastrukturne aktivnosti su nastavile austrijske vlasti (1814. - 1919.), posebice na planu restauracije spomeničke baštine, pošumljavanja, izgradnje cesta, a pogotovo morske prometne infrastrukture (Geić, 1981). Sve iznijeto omogućilo je i brži razvoj jadranskog turizma (Istra, Kvarner, Dalmacija) od sredine 19. st., a na tragu iskustava francuskih, talijanskih te grčkih i španjolskih rivijera, mahom ulaganjem stranog kapitala. Od početka 20. stoljeća do kraja tridesetih godina Dalmacija već bilježi značajne stope turističkog rasta, te intenzivniji proces osnivanja društvenih organizacija za poljepšanje mjesta i unapređenje turizma, uređenja kupališta i promenada, uz higijensko sanitarne i zdravstvene mjere za zaštitu zdravlja turista i pučanstva, a u konačnici i dioničkih društava za izgradnju hotela i gostionica sa spavaćim sobama (Vukonić, 2005). No, u to vrijeme normalne životne pa i turističke tijekove osujetio je I. sv. rat a potom i epidemija Španjolske gripe koja se proširila diljem Europe uključujući Dalmaciju. Ona je prema različitim procjenama u 1818. i 1819. g. pomorila od 50 do 100 milijuna ljudi uz gotovo deseterostruko više oboljelih. Uzročnik je bio H1N1 virus nastao kao kombinacija ptičje, svinjske i obične gripe, a prema nekim istraživačima pod nazivom Azijska gripa bio je poznat već 500 . g. p.n.e. Razmjere ove pandemije istraživači često izjednačuju s kataklizmičkom pošasti kuge u 16. st. (Cvetnić, Savić, 2018). Unatoč tada oskudnim ratnim izvorima, procjene su da je u Hrvatskoj bilo preko 100.000 žrtava, a za Dalmaciju koja je imala veliki broj tada već iscrpljenih i bolesnih vojnika te mornara u Austrougarskoj vojsci, može se procijeniti najveći udio.

Analizom osnivanja turističkih organizacija u Dalmaciji te na hrvatskom Jadranu u cjelini kroz 19. i 20. st., očito je da su one u velikom broju inicirane upravo slijedom zdravstveno lječilišnih komponenti primorskog turizma s povoljnim indikacijama u nizu bolesti. To dokazuju nazivi i programi društava i ugostiteljskih objekata (lječilišni hoteli) te njihovih osnivača (liječnici) što je slučaj i kod Higijeničkog društva u Hvaru (1868.) kao prve društvene organizacije u hrvatskom turizmu koja već u osnivačkim aktima ističe upravo „ugodnu zdravstveno poštednu klimu Hvara pogodnu za liječenje, odmor i oporavak u zimskom periodu“. Nakon toga u Hvaru počinje izgradnja više hotela lječilišnog karaktera te pratećih turističko ugostiteljskih objekata, što je slučaj i širom Dalmacije. Tek kasnije, početkom 20.st. u Hvaru i diljem Jadrana afirmira se i kupališni ljetni turizam koji se promovira i na Svjetskoj izložbi u Parizu 
1900.g. te Jadranskoj izložbi u Beču 1912. gdje se Kraljevina Dalmacija predstavila u okviru austrijskog paviljona. Od tada ovaj vid turizma prevladava sve do današnjih dana, uz nastojanja turističke organizacije da se u Hrvatskoj pa i Dalmaciji razvija cjelogodišnji turizam sukladno sintagmi HTZ „Hrvatski turizam 365", u čemu upravo zdravstveno rekreativni i kulturni turizam imaju ključnu ulogu.

\section{Sociokulturne interakcije pandemija, zdravstvene kulture i turizma Dalmacije u turističkoj eri}

\subsection{Globalni prostorno ekološki i sociokulturni procesi u kontekstu zdravstvene kulture i turizma}

Sukladno brojnim multidisciplinarnim istraživanjima danas je izvjesno kako industrijska, prometna te internetska revolucija i sveopća globalizacija, uz sve korisnosti za čovjeka donose i niz socio ekoloških te zdravstveno štetnih posljedica. To se posebno ogleda u procesima pretjerane industrijalizacije, urbanizacije, litoralizacije i metropolizacije te eksplozivne ekspanzije prometnih sustava, a slijedom toga i masovnih formi "hard" turizma. Sve to rezultira enormnim zagađenjem zraka, tla, vode i hrane, nepodnošljivom bukom i drugim polucijama koje se neadekvatno ili nikako ne zbrinjavaju odnosno razrješavaju. Ovo dovodi do nepremostivih ekoloških pa i zdravstvenih problema, te štoviše i do kataklizmičkih prirodnih katastrofa uzrokovanih klimatskim promjenama slijedom sve izraženijeg neprimjerenog odnosa čovjeka prema okolišu te prirodi koja mu bumerangom vraća neodgovorno ponašanje u segmentu ekologije i pretjeranog iskorištavanja prirodnih resursa. Iznijeto rezultira nesagledivim posljedicama na pučanstvo posebice u (neo) kolonijalizmom eksploatiranih i gospodarski te sociopolitički devastiranih zemalja trećeg svijeta i danas izloženih bijedi te bolestima pa često i pandemijama slijedom niske razine zdravstva i zdravstvene kulture te infrastrukture, uz akutni nedostatak hrane i pitke vode što je donedavno zahvaćalo populaciju od gotovo 2,5 milijardi ljudi ili trećinu pučanstva na zemlji. Najveći dio njih, uz nemoć međunarodnih institucija, danas jedini izlaz vidi u masovnim migracijama prema razvijenim dijelovima svijeta kojima smo svakodnevno suočeni. Nerazborito djelovanje čovjeka na prirodni okoliš mahom slijedom nezasitnih apetita za ekstra profitom multinacionalnih korporacija, već danas ukazuje na kobne posljedice koje očekuju čovječanstvo u budućnosti s vizionarskim porukama nekih znanstvenika "svijet se more resetirati ili će nestati." Uz izneseno, očigledan krah liberalne ekonomije s centrom pozornosti na profit i tendencije oligarha ka sve manjem izdvajanju za javne potrebe te zaposlenike, a na korist krupnog kapitala, vodi tome da paradoksalno ni najjače svjetske ekonomije (USA...) nemaju adekvatan sustav javnog zdravstva. Zemlje .,trećeg svijeta“ se i dalje bezdušno eksploatiraju te direktnim ili prikrivenim neokolonijalističkim intervencijama "dežurnih čuvara“ kvazi demokratskog svjetskog poretka, politički destruiraju pa i razaraju (Jurčić, 2020). To vodi daljem rastu siromaštva te potpunom krahu njihova zdravstva i zdravstvene kulture kao pogodnom tlu za masovna zarazna oboljenja epidemijskih razmjera. U konačnici slijedom sveopće globalizacije, one mogu zahvatiti i cijelo čovječanstvo što je evidentno i u aktualnoj pandemiji Korona virusa. $U$ namjeri osvješćivanja čovječanstva vezano za ekološke probleme, bijedu i rast siromaštva te nejednakosti i bolesti posebice u tzv. zemljama trećeg svijeta, su i učestale poruke globalnih 
humanista pa i apeli i najvećih autoriteta katoličke crkve koji u kontekstu negativnih posljedica sveopće globalizacije poručuju: „Globalizirajmo prvo one najsiromašnije", a vezano za ekološke izazove čovječanstva: „Ekološka kriza je kriza morala i zbiljski prezir spram čovjeka“. U istom kontekstu još početkom stoljeća nositelj ovog rada upozoravao je kao i mnogi drugi humanistički i ekološki educirani i osviješteni intelektualci, na opasnosti nemara prema okolišu te rasprodaje hrvatskog nacionalnog blaga poput izvora pitke vode, telekomunikacija, industrije nafte i plina s bušotinama, te bankarskog sustava... multinacionalnom kapitalu. Tome dakako treba pridodati i postupnu privatizaciju javnog zdravstva, poslijeratnu kriminalnu tajkunsku privatizaciju društvenih gospodarskih subjekata po sintagmi "200 bogatih hrvatskih obitelji", te slične kriminalne pojavnosti pojedinaca i grupa zaštićenih od vladajućih političkih pa i sudbenih struktura, kreirajući koncept. „ortačkog upravljanja“ državom i društvom. U tom smislu i mediji ustvrđuju: „Živimo u stranačkim elitama zarobljenom društvu“, gdje četvrtina populacije živi u siromaštvu te demografski slomljenom niskim natalitetom $i$ emigracijom mladih" (TV Nova ,30.09.20.). Štoviše neki u svijetu relevantni hrvatski ekonomisti i u kontekstu nepredvidljivih posljedica aktualne pandemije te stagnirajućih sociogospodarskih i demografskih trendova u Hrvatskoj u odnosu na zemlje EU, prognoziraju katastrofične posljedice po hrvatsko gospodarstvo uz ocjenu nekompetentnosti upravljanja državom od strane interesno umreženih stranačkih lobija te neučinkovitost Sabora kao pokrića promašenim potezima kadrova vladajućih struktura odabranih negativnom selekcijom isključivo između stranačkih poslušnika (Kulić, 2020). Tome treba pridodati iritirajuće činjenice o koruptivnim radnjama čak i u zdravstvu te pravosuđu kome procesuirani kriminalci pa i ratni zločinci olako izbjegavaju pravdi zastarama ili bijegom u susjednu državu u kojoj se bukvalno" štancaju", a potom u RH i nostrificiraju lažne diplome za političke i ine poslušnike, bez želje nadležnih organa za provjeru, poput već zaboravljenog slučaja lažnih branitelja. Sasvim je logično da u ovim okolnostima prezaduženi sustav zdravstva dijeli sudbinu niske učinkovitosti hrvatskog gospodarstva i društva u cjelini, te ne može zadovoljiti potrebe pučanstva i sve intenzivnijih turističkih kretanja posebice u Dalmaciji gdje boravi najveći broj turista. Ovakvo stanje zorno pokazuje činjenica da se partitokratski ustrojena Hrvatska umjesto obećavanog „švicarskog eldorada“ svrstala na začelje zemalja EU koju od kolapsa spašava tragična emigracija radno sposobnog pučanstva svojim deviznim doznakama te jadranski turizam izdašnim direktnim i multiplikativnim učincima, s kojeg izvora su, uz rasprodaju privatiziranih priobalnih nekretnina, nekada javnog dobra opće služnosti (muše), i visoki porezni proračunski prihodi kao osnova za financiranje enormnog biorokratiziranog, a neučinkovitog aparata.

Uza sve nedaće, nepravde i probleme na svjetskoj i domaćoj sceni zakon dijalektičkog razvitka društva ipak neminovno vodi napretku civilizacije te kulturno obrazovne razine ljudi uključujući i rast zdravstvene kulture, a u kontekstu turizma i objektivne psihofizičke potrebe za privremenom promjenom radne i životne sredine, aktivnim odmorom te rekreacijom pa i liječenjem i/ili rehabilitacijom u prirodi, što se sve više prakticira kroz selektivne i druge oblike suvremenog održivog turizma u čemu participira gotovo pola čovječanstva. Ove činjenice posebno dobivaju na značenju i slijedom podataka da su početkom novog tisućljeća oboljenja i smrtnost od tzv. funkcionalnih bolesti kao produkta suvremene civilizacije bila znatno veća (čak $70 \%$ oboljelih), nego od infektivnih bolesti ili pak karcinoma kao bauka današnjice (cca $12,5 \%$ ) koje su se naporima zdravstvenih institucija rapidno smanjivale. U najvećem 
broju slučajeva aktivni turistički odmor i rekreacija kao dio profilakse, liječenja i rehabilitacije korištenjem ljekovitosti zdravog prirodnog okruženja u ekološki urednim turističkim destinacijama na organizam djeluju poštedno. Oni štoviše postaju dio sveopće zdravstvene i turističke kulture modernog čovjeka, a turizam jednom od najupečatljivijih fenomena današnjice. Zdravstvena kultura modernog društva stoga podrazumijeva postojanje složenog sustava i umreženih zdravstvenih institucija koje se uz ostalo bave i određivanjem načina korištenja slobodnog vremena pa i liječenja kroz aktivni vid odmora i rekreacije. U tom kontekstu nivo zdravstvene kulture i zdravstva utječe na kvalitetu, prostorne dimenzije, vremensku distribuciju i vidove turističke aktivnosti te način korištenja prirodnih ljekovitih čimbenika u turističkim destinacijama, a štoviše i na daljnji rast zdravstvenog standarda turista pa i populacije u receptivnim područjima. To je evidentno u preko 200 turističkih zemalja s više od 10.000 destinacija diljem svijeta pa i u Dalmaciji (Geić, 2012).

\subsection{Sociokulturni položaj Dalmacije u segmentu zdravstvene kulture i turizma u povijesnim i aktualnim vremenima}

Dalmacija kao vodeća turistička i kulturna regija Hrvatske svoju bogatu milenijsku povijest kulturu i civilizaciju, urbanitet pa i odgovarajuću razinu zdravstvene kulture treba zahvaliti ponajviše svojim primorskim gradovima (komunama) koji su povijesno nastali i razvili se na tragu velikih mediteranskih civilizacija. Nažalost paradoksalna je činjenica da je Dalmacija u novoj samostalnoj Hrvatskoj izgubila vjekovima čuvanu i njegovanu regionalnu upravnu te političku, kulturnu i svaku drugu samobitnost. Ovaj u svjetskim relacijama prepoznatljivi upravni regionalni te posebice tradicijski kulturni pa i turistički identitet uključivši i sam naziv star preko dva i pol milenija (DELMATI), koga već prije 16 stoljeća slavi i prvi prevoditelj Biblije na latinski Sv Jeronim-Dalmatinac danas njen nebeski zaštitnik, izgubljen na račun apsurdnih izvedenica tipa "Splitsko dalmatinska" te sličnih županija formiranih kao što je slučaj s prekobrojnim jedinicama razmrvljene i neučinkovite lokalne uprave, isključivo po politikantskom ključu i sintagmi podijeli pa vladaj, gdje je svaki zaseok postao općina i selo gradom, a primjerice prekobrojne otočke i druge općine pa i županije decenijima se ne mogu dogovoriti ni o lociranju odlagališta vlastitih polucija. To je sve potpuno oprečno prokušano uspješnim skandinavskim modelima najviših demokratskih standarda čemu Hrvatska barem deklarativno teži. Na istom tragu je i destrukcija pa čak i gašenje dalmatinskih javnih medija kao nositelja kulture i demokratskih stečevina (Slobodna Dalmacija, HTV Studio Split, Feral...). Tome uz ostalo u sferi kulture treba dodati i nebrigu za najstariji, " pučko hrvatski" dalmatinski čakavski jezik kao bitni segment kulturnog identiteta dalmatinskog puka, kojim su uz tada službeni latinski, pisali još u vrijeme humanizma i renesanse utemeljitelji hrvatske književnosti (... "di ča slaje zvoni"- Marulić). Štoviše veliki dalmatinski i europski genije i humanista Faust Vrančić (1551. - 1617.), ga kao ravnopravnog vodećim europskim jezicima uvrštava i u svoj peterojezični rječnik. On posljednjih decenija i definitivno nestaje, o čemu sa sjetom pišu mnogi dalmatinski humanisti (,Moje ca je sve samije"- Geić, 1997), kada sve relevantne svjetske regije svoj regionalni jezik tretiraju ravnopravnim standardnom kao krucijalan segment regionalnog kulturnog identiteta.

Turističke i ekološko humanističke znanstvenike te zdravstvene djelatnike posebno zabrinjava i činjenica nekontrolirane ekspanzije masovnog (hard) turizma koji već sada ponegdje 
na Jadranu pa i Dalmaciji ozbiljno premašuje održivi prihvatni kapacitet, uz prisjećanje na zlokobnu poruku ekologa..." već dolaskom prvog turista donesena je smrtna presuda turističkom lokalitetu". Dakako to je potencirano neefikasnošću nacionalnog te regionalnog i lokalnog administrativnog ustroja, posebice u prostornom planiranju te ekološkoj zaštiti najvrjednijih prirodnih i kulturnih resursa zemlje, a time i Dalmacije kao najatraktivnije hrvatske regije. Ipak, treba se nadati da će europski koncept regionalizacije zemlje s pet statističkih regija te reforma administrativnog ustroja koja se dugo najavljuje, biti provedeni u stvarnosti s odgovarajućim rezultatima povoljnim i za ovu regiju te $\mathrm{RH}$ u cjelini. Naime apsurdno je da Dalmacija koja u svojim povijesnim lokalitetima čuva najstarije biljege hrvatske državnosti, a nekada ustrojena i kao kraljevina, kako 1919.g. ulazi i u novostvorenu državu Južnih Slavena, danas formalno živi samo kao svojevrsni povijesni relikt u memorijskom dijelu dalmatinskog puka koju bukvalno održava jedino pjesma nostalgičnih Dalmatinaca. Nažalost, uz ostalo i autentična dalmatinska (klapska- a capella) pisma unatoč zaštiti UNESCO-a kao vrhunsko svjetsko nematerijalno kulturno dobro, posljednjih godina također nestaje pred naletom zabavne šund produkcije tzv., novo „klapa“ (Intrade i sl.), koje uz blagoslov nekompetentnih glazbenih urednika i producenata derogiraju vjekovne napore dalmatinskog puka i kulturnih velikana u njenom očuvanju, te prijete zbog činjenice falsificiranja brisanjem iz registra svjetske baštine. Ovaj svojevrsni etnocid i kulturocid prema baštini nezamisliv je u povijesti europskih pa i svjetskih kulturnih naroda (Geić, 2004).

Treba istaći da su kroz hrvatsku povijest upravo Dalmacija i njeni gradovi koji su danas u svijetu nezabilježenim politikanskim upravnim ustrojem prostorno i na svaki drugi način reducirani, bili presudni, osim u kulturnom kontinuitetu, i onda kada je riječ o visokim mediteranskim tekovinama u segmentu zdravstva i zdravstvene kulture kao osnovnih čimbenika u prevenciji i liječenju različitih bolesti pa i zaraznih pandemija. Slijed mediteranskih tradicija, a time i visokih kulturnih vrednota Dalmacije ogleda se i danas kroz brojne očuvane spomeničke artefakte kulturne baštine uključujući i sferu zdravstvene kulture, koji se mogu daleko intenzivnije valorizirati u selektivnim oblicima kulturnog i zdravstvenog turizma. Štoviše, turistička kretanja snažan su poticaj rastu zdravstvene i komunalne kulture u turističkim destinacijama mediteranskog priobalja koje kroz brojne pozitivne socioekonomske učinke turizma nadoknađuju njegovo zaostajanje slijedom prelaska gospodarske moći na sjever Europe i Novi svijet. To je slučaj i s Dalmacijom, makar s izvjesnim zaostatkom zbog objektivnih (ratna stradanja), ali i subjektivnih problema, posebice u procesu političko gospodarske, sudeći po izvješćima službenih revizorskih organa, u velikoj mjeri kriminalne pretvorbe i privatizacije, realizirane i u hrvatskom gospodarskom pa i turističkom sektoru od početka devedesetih godina 20 . st.

Inače, već početkom turističke ere od sredine 19. st. bilježe se i u Dalmaciji značajne interakcije zdravstvene kulture i turizma što se ogleda u sve intenzivnijim naporima na komunalnom i higijensko sanitarnom uređenju turističkih mjesta te stvaranjem, a potom i marketinškim pozicioniranjem dalmatinskih rivijera na tragu istih diljem Sredozemlja. Sve to osim turistima logično koristi i lokalnom pučanstvu te tijekom 20. st. značajno podiže razinu zdravstvene kulture i uopće kulturnog te životnog standarda koji se u primorskoj Dalmaciji početkom novog milenija postupno približava srednjoeuropskom. Treba međutim istaći i činjenicu da od šezdesetih godina 20. st. masovni „,hard“ turizam kroz forme tzv. Balearizacije i Romagnolizacije značajno opterećuje krhku ekumenu dalmatinskih rivijera, izazivajući složene komunalne, ekološke pa i zdravstveno epidemiološke probleme te štoviše i povremene epidemije zaraznih 
bolesti. Tada zbog rasta turizma, a neodgovarajuće vodoopskrbe te odvodnje polucija i drugih relativno niskih higijensko epidemioloških standarda, Dalmacija bilježi čak 24 ozbiljne tifusno paratifusne hidrične epidemije te zaraze dizenterije, s više tisuća oboljelih turista i stanovnika (Zaostrog 1963., Omiš 1961. i 1969. Vodice 1965.). (Suić, 1969) Kako se slični problemi javljaju i multipliciraju i u drugim mediteranskim te svjetskim destinacijama reagiraju ekološki osviješteni znanstvenici te vodeće svjetske organizacije (UNEP, UNESCO, UNWTO...) kreirajući sedamdesetih godina 20. st. suvremeni koncept održivog turizma koji maksimalno štiti prostor i sociokulturno te zdravstveno ekološko okruženje turističkih područja, a koga treba sačuvati $i$ za generacije koje dolaze. O tome uz svojevrsne apele nadležnim strukturama, posebno ilustrativno pišu brojni turistički autori humanističko ekološke provinijencije: Alfier (1977), Krippendorf (1984), Smith (1986), Vukonić (1987) i dr. Nadalje, kašnjenje u izgradnji sustava kondicioniranja i recikliranja polucija kao važne higijensko sanitarne i zdravstvene komponente kvalitete života pa i turizma, što su naši mediteranski konkurenti realizirali već sedamdesetih i osamdesetih godina 20. st., izaziva značajno zagađenje mora i plaža, uz više složenih zdravstveno epidemioloških incidenata i u Dalmaciji. Posljednjih godina domaćim sredstvima te uz podršku europskih fondova i investicijskih banaka (IBRD, EBRD...), ova problematika kao i vodoopskrba otoka i zaleđa se postupno razrješava, no tempom koji ne zadovoljava narasle potrebe uz evidentne probleme posebice u Zagori i na otocima. Problem zbrinjavanja krupnog otpada i sličnih zagađenja okoliša koji remeti zdravstveno sanitarnu te epidemiološku sliku Dalmacije još je izraženiji, uz nesnalaženja Vlade i lokalnih struktura što će rezultirati penalizacijom od strane Europske komisije zbog opasnosti zaraza pa i epidemija te drugih zdravstvenih ugroza za pučanstvo i turiste.

Razvojem hotelijerstva kvaliteta hrvatske pa i dalmatinske turističke suprastrukture raste, makar ne potrebnim tempom i sukladno zahtjevima sofisticirane turističke potražnje, posebice zbog izostanka domaćeg te većeg ulaganja stranog kapitala koje ometa preveliko administriranje pa i korupcija kao posljedica političkog kadroviranja u lokalnoj i regionalnoj upravi, ali i ministarstvima te drugim relevantnim institucijama o čemu svjedoče permanenthe afere koje pravosuđe adekvatno ne razrješava. Na to Hrvatsku upozoravaju i aktualna izvješća Europske komisije tretirajući je jednom od najugroženijih zemalja EU, što unosi nepovjerenje građana, ali i stranaca potencijalnih turističkih investitora u hrvatski pravosudni sustav. Inače, akutni nedostatak očekivanih i nužnih većih ulaganja u primarne smještajne kapacitete posebice u Dalmaciji, djelomično kompenzira ekspanzija i rast kvalitete u sektoru komplementarnih kapaciteta (preko $60 \%$ ukupnog smještaja u RH u čemu predvodi Dalmacija). To unatoč nedostataka manje potrošnje $\mathrm{i}$ iskorištenosti kapaciteta, ulaganjem građana doprinosi rastu hrvatskog turizma u cijelosti pa i razini stambene, komunalne te zdravstvene kulture pučanstva na prostorima turističkih destinacija. Taj proces u posljednje vrijeme evidentan je osim u priobalju i u manje razvijenom zaleđu kroz sintagmu „Provansalizacija Dalmacije“ $i$ „Toskanizacija Istre“, što značajno doprinosi ravnomjernom razvoju ovih regija pa i Hrvatske u cjelini. 


\subsection{Utjecaj pandemije Korona virusa na hrvatski i dalmatinski turizam}

Pandemija Korona virusa SARS CoV 2 Covid-19 koju je WHO proglasila 11.ožujka 2020. suočila je svijet s globalnim izazovom bez presedana koji uz gospodarske i društvene te posebice zdravstvene implikacije izaziva snažne turbulencije unutar nacionalnih država, ali i EU te na globalnom planu. Pod utjecajem pandemije međunarodni odnosi obilježeni su novom dimenzijom nepovjerenja pa i nadmetanja velikih sila te njihovih zdravstveno epidemioloških instituta u utrci što bržeg pronalaska učinkovitog cjepiva To sve skupa testira fenomen globalizacije, krizni menadžment vlada i međunarodnih organizacija te znanstvenih zajednica, pa i međudržavnih bilateralnih odnosa posebice između velesila Kine i Amerike (USA) koja je slijedom toga istupila iz članstva WHO. Sukladno preporuci WHO svijet je primijenio niz sveobuhvatnih epidemioloških mjera a time i sociopolitičkih akcija na globalnoj i nacionalnoj razini uključujući ponegdje kompletni „lock down“ i ponašanje pod sintagmom "novo normalno" što uključuje ograničavanje kretanja i druženja ljudi, obaveze nošenja zaštitnih maski, te distancu pri kontaktima i sl. ( Polović, 2020).

Tretirana pandemija prema izvješćima medija već u početnom valu tijekom prvih 9 mjeseci zahvatila je cjelokupno čovječanstvo s preko 30 milijuna zaraženih uz milijun preminulih (krajem rujna) sa žarištima najprije u Kini, a potom Italiji, Španjolskoj, Rusiji, SAD-u, Brazilu itd. Hrvatska se u prvoj fazi pandemije, zahvaljujući pravovremenom djelovanju Nacionalnog kriznog stožera, nadležnih vladinih i lokalnih institucija, sustavu javnog zdravstva i disciplini građana relativno dobro nosila, što je rezultiralo malim brojem oboljelih i umrlih, te unatoč „lock down-u", opstanak većeg dijela gospodarskih subjekata. Uz izvjesno zakašnjenje uspjelo je i pokretanje turizma te odvijanje dijela glavne turističke sezone o čemu je praktički ovisila i sudbina pratećeg gospodarstva, pa i društva u cjelini obzirom na visoko učešće turizma u nacionalnoj ekonomiji. Situacija je međutim postala vrlo ozbiljna početkom drugog vala pandemije krajem kolovoza jer se zemlja u potpunosti otvorila turistima uz ukidanje svih restrikcija. To je izazvalo za to vrijeme neočekivano veliki broj zaraženih (preko 300 slučajeva dnevno), što se posebice uočavalo u Dalmaciji koja je glavna okosnica turističkog razvoja s polovinom svih turističkih agregata RH. Nerezonsko popuštanje Nacionalnog stožera u razini nužnih higijensko epidemioloških mjera ( noćni klubovi, masovne zabave, vjenčanja, politička i vjerska okupljanja i sl.), što nije bilo presudno za turizam ni gospodarstvo, uz boravak preko milijun turista na Jadranu izazvalo je tijekom rujna iznad 90 oboljelih na sto tisuća stanovnika s žarištem u Srednjoj Dalmaciji. Po tome je RH bila rangirana među 4 najugroženije zemlje EU što je rezultiralo njenim svrstavanjem u tzv " crvenu zonu“ te ugrozilo drugi dio sezone i posezonu, s ozbiljnim sociogospodarskim posljedicama kojima se cijela Dalmacija zbog drastične redukcije avio prometa prema hrvatskom jugu već ranije suočila. Unatoč svemu hrvatski pa i dalmatinski turizam postigao je u odnosu na mediteransku konkurenciju relativno zadovoljavajuće rezultate (50\% od rekordne 2019.g.). Pravovremenim mjerama pomoći Hrvatske vlade ugroženom gospodarstvu, a posebice turističko ugostiteljskom sektoru, izbjegnute su teže posljedice za zaposlenike i poduzetništvo. Specifična nepovoljna struktura u turističkim smještajnim kapacitetima RH s izrazitom prevagom komplementarnih kapaciteta, koja se ne bilježi kod naših mediteranskih konkurenata s učešćem od preko $50 \%$ u najkvalitetnijim primarnim kapacitetima, iskazala se u ovoj krizi kao komparativna prednost. Naime, turistička sezona 2020. u Hrvatskoj pa i Dalmaciji djelomice je spašena zahvaljujući upravo komplementarnim kapacitetima, gdje je mogućnost 
zaraze zbog odsustva masovnosti bila znatno niža. To je postignuto unatoč propustima i nedosljednosti nacionalnog kriznog stožera po mnogima opterećenog politikantstvom, uz postupno gubljenje autoriteta kod građana što je bilo evidentno posebice u drugom valu pandemije, s posljedicama koje je prema izjavama medicinskih autoriteta (Đikić i dr. 2020.), teško moguće sagledati. Nepoznavanje uzroka, te svih mogućih manifestacija, roka trajanja i posljedica pandemije Covida -19 na globalnom planu, uz uobičajeno dugi vremenski rok do registracije te primjene i djelovanja više vrsta cjepiva , unatoč iznimnim naporima WHO te svjetskih zdravstvenih eksperata i institucija, dalo je cijelom problemu dodatnu dozu neizvjesnosti razini čovječanstva, što se posebice reflektira u gospodarskim djelatnostima sektora putovanja i turizma koje su pandemijom najugroženiji. Početkom listopada 2020. situacija s pandemijom se prema izvješćima WHO i nadležnih nacionalnih organizacija pogoršava s 35 milijuna oboljelih u svijetu, te ponegdje preko 50000 novooboljelih dnevno (Rusija) i više od 200.000 ukupno preminulih (USA) uz rigorozne epidemiološke mjere koje remete gospodarski i društveni život i diljem EU. Hrvatska se tada približila brojci od 20.000 ukupno zaraženih te 540 oboljelih u 24 sata, što je umnogome bio rezultat nepridržavanja preporučenih mjera Stožera koji gubi početno stečeni kredibilitet. Krajem studenog situacija diljem svijeta eskalira s preko 60 milijuna oboljelih i 1,5 milijuna preminulih uz žarišta u USA, Rusiji pa i vodećim zemljama EU gdje se uvode drastične mjere policijskog sata i „lock downa“ u ugostiteljstvu, kulturi, školstvu i sl., uz prijetnju kolapsa zdravstvenog sustava. Neodgovornost građana, ali i nedosljednost te nedostatnost poduzetih mjera unatoč apelima vodećih hrvatskih zdravstvenih i drugih autoriteta, čini da Hrvatska ubrzano bilježi daljnje negativne rekorde te unatoč postupnom pooštravanju mjera krajem studenog ima preko 4000 dnevno oboljelih i 70 umrlih u 24 sata ili ukupno od početka pandemije preko 150000 oboljelih i 3000 umrlih, uz uzlazne trendove te opasnost sloma preopterećenog zdravstvenog sustava. Hrvatska se tada svrstava među ugroženije zemlje EU, s žarištima u Dalmaciji, Zagrebu, te u sjevernoj Hrvatskoj koje su u odnosu na broj stanovnika postale najugroženije regije EU. Slijedom toga se poduzimaju još drastičnije mjere na tragu istih iz prvog vala pandemije koje se tijekom siječnja 2021. postupno pooštravaju uz ograničenja okupljanja te zabranu rada ugostiteljskih objekata i kulturnih te sportsko rekreativnih institucija. Tada svijet već premašuje broj od 100 milijuna oboljelih i 2 milijuna umrlih od čega samo u USA preko 400 tisuća, te u Brazilu preko 300 tisuća, uz dalju progresiju, a neke europske zemlje uvode nove drastične mjere policijskog sata i zatvaranja granica te uslužnih djelatnosti, uz prosvjede ugroženih poduzetnika i pučanstva. Hrvatska unatoč poduzetim restriktivnijim mjerama sredinom siječnja 2021.g. bilježi blizu 5000 oboljelih te 100 preminulih dnevno te od početka pandemije ukupno 200.000 oboljelih i 5000 umrlih. Ipak slijedom poduzetih strožih mjera Stožera, broj zaraženih se krajem siječnja postupno smanjuje (cca 10\% od testiranih s trendom pada), uz paralelno vrlo blago relaksiranje mjera zbog opasnosti širenja novih sojeva virusa (britanski, južnoafrički, brazilski..) koji su tada već bili registrirani i u susjednim zemljama, te opasnosti pojave mogućeg trećeg vala. Imajući sve iznijeto u vidu, budućnost „korona krize", te njene popratne posljedice su i nadalje potpuno neizvjesne u segmentu zdravstvenih, ali i gospodarskih te društvenih šteta, unatoč pronalaska i od nadležnih institucija odobravanja, a potom i postupne primjene više vrsta cjepiva te početka cijepljenja od kraja 2020., a u Europskoj uniji pa i Hrvatskoj početkom 2021. g. Taj je proces nažalost obilježen velikom globalnom aferom nepridržavanja proizvođača cjepiva ugovornih odredbi u isporukama, čime je posebno bila pogođena EU a time i Hrvatska. To je međutim globalno minorna stvar u 
odnosu na činjenicu da najveći dio siromašnih zemalja trećeg svijeta do cjepiva uopće ne može doći, što u konačnici osim dubokog etičkog pitanja dovodi do zdravstvene nesigurnosti pola zemaljske populacije pa slijedom toga i cijelog čovječanstva koje može biti ugroženo mutacijama virusa upravo iz ovih zemalja. Na ovom tragu su već duže vrijeme apeli svjetskih autoriteta poput Svetog oca Pape te čelnika Svjetske zdravstvene organizacije, UN, EU i drugih globalnih institucija koje brinu o zaštiti ugroženih socijalnih skupina i zemalja diljem svijeta, nažalost s neizvjesnim ishodom barem u doglednoj budućnosti. Analizirajući situaciju s pandemijom Korona krize u Hrvatskoj, a u kontekstu teme ovog rada potrebno je konstatirati da za razliku od discipliniranih građana i nadležnih organa Istre s visokom razinom kulture pa i zdravstvene kulture, gdje je situacija uvijek bila znatno povoljnija od ostatka zemlje, Dalmatinci su se ignoriranjem preporučenih mjera te slijedom toga često i najveće incidencije po stanovniku, pokazali nedostojni visoke razine kulturne, a time i zdravstvene svijesti svojih predaka koji su kroz povijest unatoč izraženim migracijskim kretanjima zadržali kulturu pa i zdravstvenu kulturu na razini euro mediteranskih tradicija. Imajući to u vidu kao i odnos prema pogibelji aktualne pandemije koja je zdravstveni sustav pa i cijelo hrvatsko društvo, posebno nakon katastrofalnih potresa u Zagrebu i na Banovini dovela do teških iskušenja, treba apostrofirati i probleme latentnog postojanja drugih negativnih događanja u sferi društvene patologije. To su prema svakodnevnim medijskim izvješćima odnos prema prostoru i prostornom planiranju te ekologiji, slabosti gospodarstva i krah poljoprivrede, kriminal i korupcija te politikanstvo i neučinkovitost u organima vlasti i sudstvu, ksenofobni ispadi političkih i navijačkih skupina, problemi rasta ovisnosti o narkoticima uz depopulaciju i rast emigriranja mladih i sl., što je evidentno i u Dalmaciji . Slijedom iznijetog nužno se zapitati. „Quo vadis Dalmacijo"?, te aktualizirati još početkom novog milenija upućen apel uglednog dalmatinskog skladatelja i humaniste Ljube Stipišića-Delmate: "Vrati se (dalmatinski) čovječe dokjoš imaš kome”, uz parafrazu lucidne izrijeke W. Churchila: "Hrvati (pa i Dalmatinci) nisu u stanju konzumirati enormno bogatstvo svoje kulture ipovijesti".

\section{Zaključak}

U zaključku rada „Sociokulturne reminiscencije pandemija, zdravstvene kulture i turizma u Dalmaciji“ bilo je oportuno analizirati pojavnosti te stečena iskustva i pouke tijekom milenijske svjetske povijesti, kada su pandemije trajale relativno dugo i zahvaćale ogroman broj pučanstva uz veliki mortalitet te se ponavljale gotovo u svakoj generaciji. Ipak, za vjerovati je da će suvremena svjetska znanost pravovremeno naći globalno učinkovita rješenja koja će definitivno suzbiti pandemiju sukladno visokoj razini civilizacijskih, a pogotovo medicinskih dostignuća čovječanstva na pragu novog milenija. Obzirom na članstvo RH u Europskoj uniji i umreženost naših zdravstvenih institucija s europskim, te unatoč značajnog odlijeva vrhunskih kadrova u inozemstvo još uvijek relevantnim potencijalima javnog zdravstva, takva rješenja će zasigurno biti dostupna i hrvatskim građanima. To će uz uvjet izbjegavanja politikantstva u odlukama Stožera te veću procijepljenost i samodisciplinu građana, voditi uspješnom kraju u borbi protiv ove pandemije koja je obilježila 20. stoljeće u svijetu pa i Dalmaciji te Hrvatskoj u cjelini. 


\section{LITERATURA}

1. Alfier, D., ( 1977./1994.), Turizam, izbor radova, Institut za turizam, Zagreb

2. Arsentijević, S., (1973.), Filozofski sinkretizam antičke medicine, Zbornik 23. znanstvenog skupa (Split), Naučno društvo za historiju zdravstvene kulture, Beograd

3. Ateljević, I., (2020.), Transforming the (tourism) world for good and (re)generating the potential "new normal", Tourism Geographies

4. Antić, D., (2020.), Zarazne bolesti u svijetu, Internet Portal livescence hr. 2020.

5. Babić, I., (1984.), Prostor između Trogira i Splita, Kulturno historijska studija, Muzej grada, Trogir

6. Babić, I. et al., (1987.), Kulturno blago Trogira, Turistkomerc, Zagreb

7. Bazala, V., (1973.), Uloga talijanskih sveučilišta na medicinu Dalmacije, Zbornik 23. Znanstvenog skupa ( Split), Naučno društvo za historiju zdravstvene kulture, Beograd

8. Bilen, M., Bučar, K.,( 2004.), Turistička geografija svijeta, Mikrorad. Zagreb

9. Cohen, E., (1998.), Tourism and AIDS in Thailand, Annals of Tourism Research, 15/4,

10. Cvetnić, Ž., Savić V., (2018.), Pandemije kuge kroz povijest, Hrvatski veterinarski institut, Zagreb

11. Cvetnić, Ž., (2020.), Pandemije velikih boginja, Hrvatski veterinarski institut, Zagreb

12. Dellale, don I., (1936.), Vodić o prošlosti i životu Trogira, Društvo za unapređenje turizma..., Trogir

13. Đikić, I., (2020), Intervju, TV Nova, 24.09. 2020.

14. Drache, D., (2003.), Media Coverage of the 2003. SARS Outbreak, York University, Toronto

15. Geić, S., (1971.), Klimatske prilike i zdravstveno rekreativni turizam na trogirskom primorju, Znanstveni simpozij „O 700. obljetnici ljekarne u Trogiru, Institut za povijest zdravstvene kulture Jugoslavije, Beograd

16. Geić, S., (1973.), The interaction between Tourism and Hygienic culture, I. Simposiomedico Italo- Yugoslavo, Pescara, Split

17. Geić, S., (1981.), Društveno ekonomske komponente razvoja turizma Trogira, Muzej grada, Trogir

18. Geić, S., (2002.), Turizam i kulturno civilizacijsko nasljeđe, Veleučilište u Splitu, Split

19. Geić, S., (2004.) Povratak iskonu - Klapa Trogir, Kulturološka monografija, Slobodna Dalmacija, Split

20. Geić, S., (2008./12.), The influence of tourism on health and health culture in the globalisation era, Zbornik Simpozija "Era nove ekonomije i novih zanimanja- Stres i mobing", Udruga Split-zdravi grad, Split

21. Geić, S., (2007.), Organizacija i politika turizma, Sveučilište u Splitu, Split

22. Geić, S., (2011), Menadžment selektivnih oblika turizma, Sveučilište u Splitu, Split

23. Geić, S., (2016.), Turizam- Osnove, organizacija, ekonomika, Visoka škola ASPIRA, Split

24. Glasinger, L., (1971.), Organizacija zdravstvene službe u srednjevjekovnom Trogiru, Zbornik Simpozija „O 700. obljetnici spomena ljekarne u Trogiru, Institut za povijest prirodnih i medicinskih znanosti JAZU, Zagreb 
25. Grabovski. P. et al., (2005), Serve acute respiratory sindrom (SARS), Turism and Media, I.J. of Tourism Research, 7/1 2005.

26. Harari, Y. N., (2015.). Kratka povijest čovječanstva (Prijevod) Fokus , Zagreb.

27. Ivanišević. G., Potrebica S., ( 2002.), Prirodni ljekoviti činitelji u promicanju zdravlja u 21. st., Akademija medicinskih znanosti Hrvatske, Zagreb

28. Kapor, A., (1973.), Neki domaći zdravstveni radnici u 18. i 19 st., Zbornik 23. Simpozija (Split), Naučno društvo za historiju zdravstvene kulture Jugoslavije, Beograd

29. Kečkement, D., (1973.), Prilozi opisu i povijesti splitskog lazareta, Zbornik 23. znanstvenog skupa (Split-Pescara) , Naučno društvo za historiju zdravstvene kulture, Beograd

30. Knez J., Antić D. (2020.), Pandemije zaraznih bolesti u svijetu, Internet portal, Lider, Zagreb

31. Kordić, Š., (1973), Profesionalna deontologija liječnika Dalmacije u 19. st., Zbornik 23. Simpozija ( 8plit), Naučno društvo za historiju zdravstvene kulture Jugoslavije, Beograd

32. Krapf, K., Hunziker V., (1963.), Le et l' importance du tourisme international, UN, Rome

33. Krippendorf, J., (1975.), Die Landschafts fresser, Hallwag Verlag, Stutgart

34. Kulić, S., (2020) , Očekivani trendovi hrvatskog gospodarstva, Intervju, Podkast Velebit

35. Laine P., (1980.), Liberations de tourismus, Paris

36. Marasović, T., (2001.), Kulturna baština I., Veleučilište u Splitu, Split

37. Marković, S. i Z., (1966.), Osnove turizma, ŠK Zagreb

38. Meyer, K.F. (1961.), Plague: in Hull, T.G. Disieses Transmitted from Animals to Man, Springfild, Illinois

39. Pančić-Kombol, T., (2000.), Selektivni turizam, TMCP Sagena, Matulji

40. Petrić, L., (2006.), Uvod u turizam, Ekonomski fakultet u Splitu, Split

41. Piplović, S., (1997, 2002.), A. Hauser u Dalmaciji, Društvo prijatelja baštine, Split

42. Plinije, (141.), Historia naturalis III. Roma

43. Polović , J. (2020.), Covid 19 kao sigurnosni izazov- teorija zavjere ili pitanje koje zahtjeva odgovore, Croatian Assosiation of International Studies, Zagreb,

44. Rusell, J. C., (1966.), The earlier plague in: The population of Medieval Egypt, American research center, Kairo

45. Smith, M. K., (2003.), Issues in cultural tourism studies, Rootledge, London

46. Smith, V., (1986.), Host and Guests, The antropology of Tourism, Philadelphia

47. Suić, M., (1969.), Posljeratne hidričke epidemije u Dalmaciji, JAZU Zagreb

48. Suić, M., ( 1970.), Kolera i turizam, Privreda Dalmacije br.11-12, Split

49. Škobalj, A., (1970.), Obredne gomile, Sveti Križ, Čiovo

50. Tartalja, H., (1971.), Naša najstarija ljekarna, Zbornik Simpozija „O 700. Obljetnici ljekarne u Trogiru", Institut za povijest prirodnih i medicinskih znanosti JAZU, Zagreb

51. Velnić, V. J., (1973.), Međuodnos medicine i farmacije s obje strane Jadrana, Zbornik 23. Znanstvenog skupa (Split), Naučno društvo za historiju zdravstvene kulture Jugoslavije, Beograd

52. Vujević, I., (2005.), Gostiteljstvo i turizam, EF u Splitu, Split 
53. Vukonić, B., (2005.) Povijest hrvatskog turizma, Prometej, Zagreb

54. Vukonić, B. et al., ( 1987.), Turizam i razvoj, Mikrorad, Zagreb

55. Wang, J., (2003.), Learning from SARS to improve Hotel Menagement, Tourism Tribune $18 / 4$

56. Zang, G., (2003.), China Tourism Industry: The impact of SARS and Rejuvenation, Beijing Social Science Press

Summary

\section{SOCIOCULTURAL REMINISCENCIES OF PANDEMICS,HEALTH CULTURE AND TOURISM IN DALMATIA}

Throughout its millennial history, humanity has been confronted with numerous infectious diseases and even global pandemics since time immemorial, with an insufficient level of health culture. Among the most famous and most terrible pandemics, the source and focus of which was most often in the Far East with a low health culture were pandemics of leprosy, plague, smallpox, cholera, tuberculosis, malaria, and the latest pandemic Corona virus SARS cov-2 covid-19 They also affected our region and Dalmatia, which has always had extensive communications throughout the Mediterranean and the world. Half a billion people or 2/3 of the inhabitants of Europe and its recurrences are recorded until the beginning of the 21st century. The development of mass tourism with all the health benefits of temporary changes in the working and living environment and living in healthsaving areas (sea, lakes, mountains ...), due to large globalized intercontinental migrations at the same time results in large pollution and environmental destruction and intensive contacts for the spread of epidemics pai pandemic infectious diseases. Positive but also negative experiences and the scale of pandemics of infectious diseases and activities for their prevention and control are considered on a global scale and especially in the area of the famous Croatian Mediterranean region of Dalmatia, as a crossroads of demographic, economic and cultural communications to Europe and the world. Understanding and analyzing the occurrence and legality of occurrence, development, spread and duration of periodic recurrence of epidemics and pandemics, as well as their suppression and prevention throughout the millennium history, with sociocultural and touristic interaction which is discussed in this paper, can be a valuable reference point in the current pandemic SARS Cov-2 Covid 19, which has seriously threatened the world with so far (31.01.21.) an estimated over 100 million patients and 2 million deaths (in Croatia over200 000 patients and 5000 deaths) with, in some european countries, a worrying progression that despite the efforts of the health epidemiological profession is not waning. However, with the drastic measures taken by the National Staff, the situation with the pandemic at the end of January 2021 is gradually easing, which allows for a cautious relaxation of measures. Following this is the announcement of further cautious easing of measures with the intention that Croatia, as a "corona free" destination, welcomes the upcoming tourist season on which the entire Dalmatian and whole Croatian economy depends.

Keywords: tourism, Covid 19, health culture, history, pandemics, Dalmatia. 